\title{
National environmental performance: an empirical analysis of policy results and determinants
}

\author{
DANIEL C. ESTY \\ Yale Law School and Yale School of Forestry and Environmental Studies, \\ P.O. Box 208215, New Haven, CT 06520-8215, USA. Tel: (203) 432-6256. \\ E-mail: daniel.esty@yale.edu
}

MICHAEL E. PORTER

Harvard Business School, Soldiers Field Road, Boston, MA 02163, USA.

\begin{abstract}
Effortsto identify the determinants of environmental policy success at the national level have largely been anecdotal and case study based. This article seeks to identify empirically the factors that drive environmental performance as measured by levels of urban particulates and sulfur dioxide and energy use per unit of GDP. Although the data are imperfect and causal linkages cannot be definitively established, the statistical analysis presented suggests that environmental results vary not only with income levels as suggested by the environmental Kuznets Curve literature but also with both the sophistication of a nation's regulatory regime and, perhaps more notably, its broader economic and social context. Thus, at every level of development, countries face policy choices that determine environmental quality in important ways. Strong environmental performance appears to be positively correlated with competitiveness, putting into question the presumed trade-off between economic progress and environmental gains. Although preliminary, these results provide evidence that environmental decision making can be made more data driven and analytically rigorous.
\end{abstract}

Concern for the environment exists in every country. But, despite the emergence of significant pollution control and natural resource management programs in most nations, little rigorous analysis has been done to identify the factors that determine whether environmental efforts succeed. Research to date has put forward theories and explored case studies, but systematic statistical investigations in the environmental arena have been limited. Within the discipline of economics, considerable focus has been given to the relationship between environmental outcomes and national income (Shafik and Bandyopadhyay, 1992; Grossman and Krueger, 1995; Harbaugh et al., 2000). This Environmental Kuznets Curve (EKC) literature has broadened beyond the income-environment relationship to examine a variety of additional impacts on environmental performance, including corruption (Lopez and Mitra, 2000), freedom (Barrett and Graddy, 2000), inequality (Torras and Boyce, 1998), openness to trade (Suri and 
Chapman, 1998; Antweiler et al., 1998), energy (Suri and Chapman, 1998), and the spatial density of economic activity (Kaufmann et al., 1998).

In the environmental field, a number of initiatives have been launched to develop metrics or indicators of environmental performance. ${ }^{1} \mathrm{~A}$ few efforts have been made to use regression analysis or other advanced statistical techniques to explore the relationship between policy choices and environmental performance (York et al., 2003; Dasgupta et al., 2001, 2002; Panayotou, 1997). But none of these efforts has examined a large number of countries (including both developed and developing countries) across a broad spectrum of possible policy determinants.

The resulting knowledge gap is unfortunate. Without solid evidence on how regulatory choices and a nation's underlying economic and legal system affect environmental performance, policies are often based on crude analysis, heated rhetoric, and imprecise concepts such as 'sustainable development'. The lack of systematic data and analysis fuels the long-standing controversies over the role of environmental outcomes in sustaining economic growth over the long term (Panayotou and Vincent, 1997; Panayotou, 2000), whether environmental gains must come at the expense of competitiveness (Porter and van der Linde, 1995; Jaffe et al., 1995; Esty and Porter, 1998), and the contours of the optimal environmental strategies for developing countries. More sophisticated metrics together with objective ways to gauge the success of environmental policies offer a constructive way forward in this highly contentious arena in which divergent points of view are strongly held (Esty, 2002).

In this paper, we take a step towards developing a set of empirical tools to identify the key policy options and to test their links to improved

${ }^{1}$ These 'indicator' efforts include: the Environmental Sustainability Index developed by the Yale Center for Environmental Law and Policy and Columbia University's Center for International Earth Science Information Network in collaboration with the World Economic Forum (WEF, 2001; Esty et al., 2005); the Living Planet Campaign sponsored by the World Wildlife Fund (Ricketts, 1999); the 'Weight of Nations' study conducted by the World Resources Institute with partners in Germany, Austria, the Netherlands, and Japan (Hammond et al., 1995); initiatives by the Organization for Economic Cooperation and Development $(1993,1998)$ and the UN Commission on Sustainable Development (1996); the International Institute for Sustainable Development (Bossel, 1999); the informal 'Consultative Group on Sustainable Development Indicators' (International Institute for Sustainable Development, 1999); the UN Environment Programme (Bakkes et al., 1994); the European Union (Eurostat, 1999); the World Business Council for Sustainable Development $(1998,1999)$ (Verfaille and Bidwell, 2000); and the Boston-based CERES group (1997) as well as a number of national sustainable development councils and projects. A few studies have begun to analyze the links between corporate environmental performance and corporate profitability, most notably the corporate environmental rankings done by INNOVEST (Dixon, 2002) and by the Dow Jones Sustainability Index (2000). Some efforts have been made to understand partial determinants of environmental quality (Panayotou and Vincent, 1997). The analysis presented here builds on prior efforts of Esty and Porter $(2000,2002)$. Earlier versions of the present analysis appeared in the 2001 Global Competitiveness Report (Esty and Porter, 2001) and (Esty and Cornelius, 2002). 
environmental performance. In particular, using statistical methods, we examine differences in environmental results as measured by levels of air pollution (looking at both particulates and $\mathrm{SO}_{2}$ ) and energy use across countries. We seek to explain these differences by analyzing cross-country variations in policy choices and regulatory structures.

Although the data are imperfect, the statistical methods employed are necessarily crude, and the lack of time series data prevents a definitive test of causality, a number of interesting relationships emerge. Consistent with the EKC literature, we find a significant correlation between income and environmental performance, suggesting that alleviating poverty should be seen as a priority for environmental policy makers. Moreover, our data also reveal dramatic differences in environmental performance among countries at similar economic levels. This finding suggests that environmental results are not merely a function of economic development but also a consequence of policy choices. Indeed, this initial effort to identify what - other than income - determines environmental policy results emerges as the central contribution of our analysis. In this regard, a country's broader economic system, legal structure, and other institutional underpinnings appear to significantly shape environmental performance. On the purported tradeoff between being 'green' and being competitive, we find no evidence that improving environmental quality compromises economic progress. To the contrary, strong environmental performance is positively correlated with competitiveness.

\section{Modeling environmental performance and its causes}

Environmental output data are notoriously spotty, unreliable, and uneven, as are data on the characteristics of national regulatory regimes. Establishing a sufficient database for a broad empirical analysis is therefore no small undertaking. ${ }^{2}$ Looking across dozens of possible variables in the ESI data set, we found just three measures of environmental performance that seemed reliable enough and available for a large enough number of countries to be of use in our analysis. The first is urban particulate (airborne dust) concentrations, derived from World Bank and World Health Organization (WHO) data. This variable provides a measure of the average particulate concentration in the air (airborne dust) of each country's cities. A higher concentration indicates more pollution and thus worse air quality.

The second usable performance measure is mean urban sulfur dioxide $\left(\mathrm{SO}_{2}\right)$ concentrations. ${ }^{3}$ This measure is also drawn from World Bank and WHO data. Again, higher figures represent worse air pollution. Our third

${ }^{2}$ For a more complete discussion of the data gaps that plague the environmental domain, see World Economic Forum (2002; Esty et al., 2005).

${ }^{3}$ Particulates and $\mathrm{SO}_{2}$ are both core elements of air pollution, making ambient levels a direct measure of environmental performance. We focus on urban pollution levels because it is in cities where data are collected and where public health issues arise. As appendix A discusses, our figures for each country are based on weighted (by population) average concentrations across all cities in a country where measurements are available. 
environmental performance measure gauges energy efficiency. ${ }^{4}$ Using US Department of Energy data, we measure total energy consumption per unit of a country's GDP. Higher figures represent more energy consumed per unit of economic output and thus greater energy inefficiency and weaker environmental performance. ${ }^{5}$ Urban particulate data are available for 42 countries. The $\mathrm{SO}_{2}$ rankings cover 47 countries. Energy usage data are available for 71 countries. $^{6}$

We hypothesize that environmental performance results from two broad sets of independent variables. As shown in figure 1, one set, which we term the environmental regulatory regime, is comprised of measures of various aspects of a country's environmental regulatory system, including standards, implementation and enforcement mechanisms, and associated institutions. These variables capture regulatory elements that directly affect pollution control and natural resource management.

The second set of independent variables, which we term economic and legal context, contains indicators of a country's more general administrative, political, scientific, and technical capabilities and institutions. We thus include measures of the extent to which the rule of law is respected, property rights are protected, and the country exhibits technological strength. These variables permit us to test the hypothesis that a nation's environmental regulatory regime will be more effective if the economic and legal context in which it operates is sound. The data for the independent variables come from two sources: the World Economic Forum's Environmental Sustainability Index (WEF, 2002) ${ }^{7}$ and (2) the Global Competitiveness

${ }^{4}$ Although energy use is not a direct pollution measure, it is an important indirect measure of a society's environmental focus and performance. This variable provides a gauge of the eco-efficiency or resource productivity of a society, especially when denominated by GDP. Energy consumption is, moreover, highly correlated with many types of pollution, most notably greenhouse gas emissions. It is also highly regulated in all societies - from carbon taxes in a few countries such as Sweden, to gasoline taxes across most of the world, to corporate average fuel efficiency (CAFE) standards for vehicles in the United States, to appliance efficiency labeling requirements in the United States and elsewhere.

${ }^{5}$ In comparing this measure across countries, we need to account for the fact that Russia and the countries of the former Soviet bloc operated for decades under an energy regime with prices set well below market prices. This history has left a legacy of energy inefficiency in these countries that is only slowly being corrected. We therefore include a dummy variable in our model to control for this history, which proves to be highly significant statistically.

${ }^{6}$ Almost all prior studies of the determinants of environmental performance have relied on much smaller numbers of countries. The size of this analysis (4271 countries) represents an important step forward, but it creates some difficulties as all of the data sets must then have comparable breadth.

7 The Environmental Sustainability Index (ESI) initiative was undertaken by the World Economic Forum's Global Leaders for Tomorrow Environmental Task Force, based on methodologies developed by the Yale Center for Environmental Law and Policy (YCELP) and the Center for International Earth Science Information Network at Columbia University (CIESIN). It draws on data sets from a variety of recognized source, including the World Bank, the World Health 


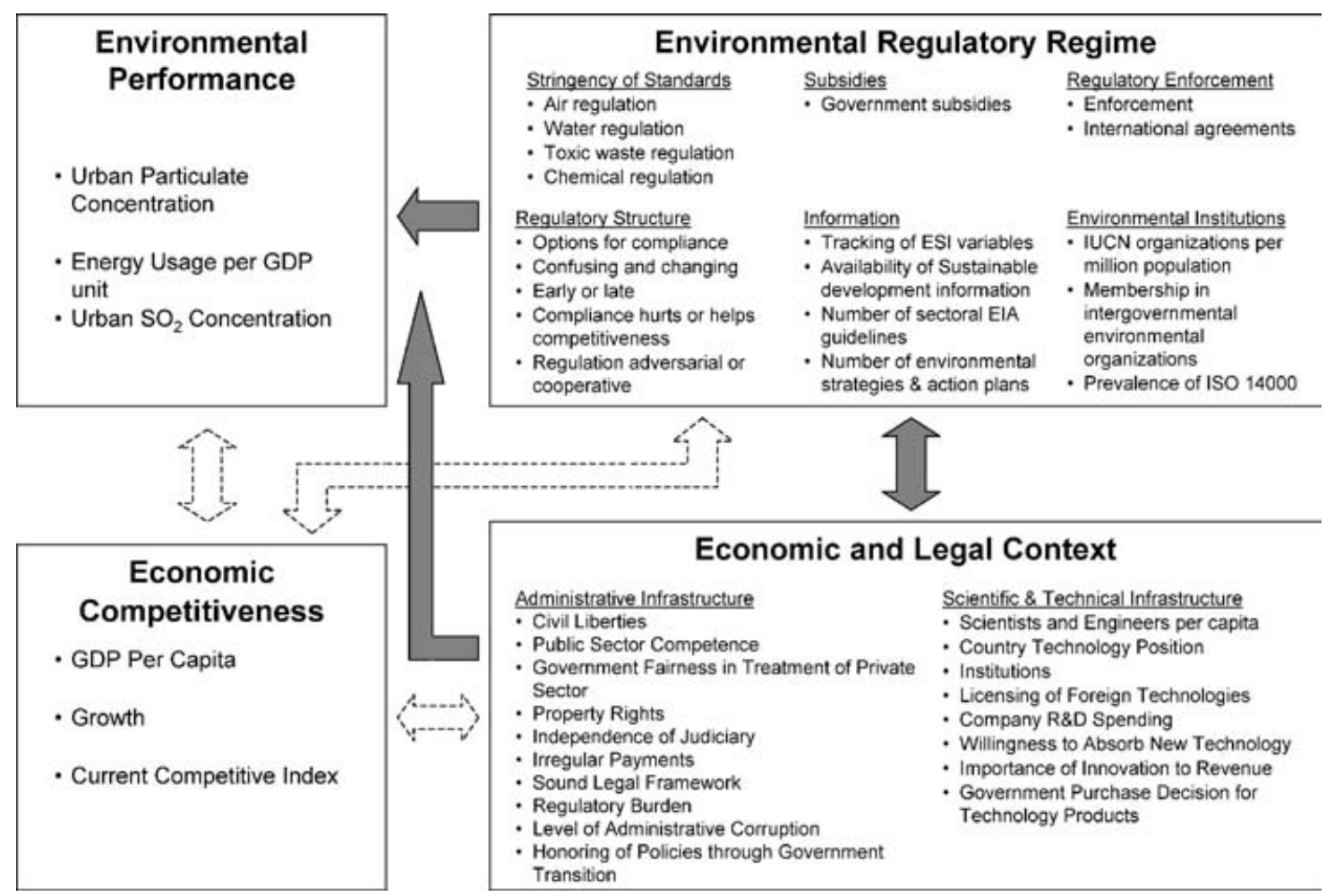

Figure 1. Determinants of environmental performance 
Report (GCR) survey ${ }^{8}$ of almost 4,000 business and government leaders in more than 50 countries.

The dotted arrows in figure 1 represent the final stage of the analysis, in which we examine the connection between environmental results and economic success. In particular, we explore the relationship between our specified environmental performance measures and GDP per capita, as well as the relationship between an index measuring the overall environmental regulatory regime, the Environmental Regulatory Regime Index (ERRI), and GDP per capita. We also examine the relationship between the ERRI and a measure of national competitiveness (Porter et al., 2001). These relationships shed light on the long-standing debate over the extent of the trade-off between environmental progress and economic success - a question of particular interest in the developing world.

\section{Measures of environmental performance}

Table 1 provides absolute rankings by country for each of the three environmental performance measures. ${ }^{9}$. Figures 2, 3, and 4 plot the relationship between each measure of environmental performance and GDP per capita. One pattern is immediately discernable across all three measures: richer countries achieve better results than poorer ones. The improvement of environmental performance as income rises is most pronounced with regard to urban particulates and energy efficiency and least strong for $\mathrm{SO}_{2}$ emissions. Among lower-income countries, the variance on all three measures is particularly high relative to that of more

Organization, and other public and private institutions. For more detail, see the 2002 ESI at www.yale.edu/envirocenter/esi or www.ciesin.columbia.edu/ indicators/esi.

${ }^{8}$ While cross-country survey data have well-understood limitations, the World Economic Forum survey - carried out by researchers from Harvard University with partner organizations from more than 50 countries - draws on the views of top business leaders, many of whom work for multinational companies and have experience across many countries. Similarly, the government leaders surveyed almost all work in a context that provides them with a perspective on the economies and regulatory systems of many countries. To assess the validity of responses within countries, we conducted an ANOVA analysis for each GCR survey measure. Regressing individual survey responses on a complete set of country dummy variables allows us to calculate the share of the variation (across individual responses) that results from systematic difference in the average response across countries. With an average of more than 60 respondents per country, the degree of within-country consensus is striking. For all measures, the proportion of variation due to country differences is statistically significant. For two-thirds of the variables used in our analysis, more than 30 per cent of the overall variation in the responses is driven by country-specific differences for that measure. For the regulatory stringency variables and some others, the proportion is 50 per cent or more.

${ }^{9}$ Both the US and the UK track smaller particulates ( 2.5 micron versus 10 micron) than those monitored by the rest of the world. The US and UK emphasis follows the most recent medical evidence, which suggests that it is the smaller particles that penetrate deep into the lungs and present a real health threat. 
Table 1. Absolute environmental performance by country

\begin{tabular}{|c|c|c|c|c|c|c|c|c|}
\hline \multicolumn{3}{|c|}{$\begin{array}{l}\text { Urban particulate concentration* } \\
\text { (per city population) }\end{array}$} & \multicolumn{3}{|c|}{$\begin{array}{l}\text { Urban } \mathrm{SO}_{2} \text { concentration* } \\
\quad \text { (per city population) }\end{array}$} & \multicolumn{3}{|c|}{$\begin{array}{r}\text { Energy usage } \\
\text { (per mil. } \$ \text { GDP) }\end{array}$} \\
\hline Rank & Country & Annual mean & Rank & Country & Annual mean & Rank & Country & Bil. Btu \\
\hline 1 & Sweden & 9.0 & 1 & Argentina & 1.02 & 1 & Denmark & 4.84 \\
\hline 2 & Norway & 10.3 & 2 & Lithuania & 2.10 & 2 & Switzerland & 5.19 \\
\hline 3 & France & 14.2 & 3 & New Zealand & 3.49 & 3 & Japan & 6.55 \\
\hline 4 & Iceland & 24.0 & 4 & Finland & 4.38 & 4 & Italy & 6.66 \\
\hline 5 & New Zealand & 27.3 & 5 & Iceland & 5.00 & 5 & Ireland & 6.85 \\
\hline 6 & Switzerland & 30.7 & 6 & Sweden & 5.23 & 6 & Austria & 7.09 \\
\hline 7 & Canada & 31.3 & 7 & Latvia & 5.36 & 7 & Germany & 7.28 \\
\hline 8 & Netherlands & 40.0 & 8 & Norway & 5.47 & 8 & France & 7.39 \\
\hline 9 & Australia & 43.2 & 9 & Denmark & 7.00 & 9 & Finland & 8.37 \\
\hline 10 & Germany & 43.3 & 10 & Portugal & 9.22 & 10 & United Kingdom & 8.59 \\
\hline 11 & Japan & 43.6 & 11 & Netherlands & 10.00 & 11 & Spain & 8.73 \\
\hline 12 & Austria & 45.7 & 12 & Romania & 10.00 & 12 & Honduras & 8.97 \\
\hline 13 & Finland & 49.9 & 13 & Spain & 11.00 & 13 & Mauritius & 9.11 \\
\hline 14 & Argentina & 50.0 & 14 & Thailand & 11.00 & 14 & Sweden & 9.14 \\
\hline 15 & Portugal & 50.4 & 15 & Switzerland & 11.34 & 15 & Israel & 9.96 \\
\hline 16 & Venezuela & 53.0 & 16 & Germany & 12.80 & 16 & Peru & 10.81 \\
\hline 17 & Czech Republic & 58.4 & 17 & Canada & 12.87 & 17 & Netherlands & 11.01 \\
\hline 18 & Denmark & 61.0 & 18 & Australia & 13.17 & 18 & Slovenia & 11.26 \\
\hline 19 & Hungary & 63.7 & 19 & Austria & 13.21 & 19 & Australia & 11.46 \\
\hline 20 & Slovak Republic & 64.5 & 20 & France & 13.89 & 20 & Guatemala & 11.52 \\
\hline 21 & Spain & 72.7 & 21 & United States & 15.43 & 21 & Portugal & 11.77 \\
\hline 22 & Romania & 82.0 & 22 & Italy & 15.55 & 22 & Belgium & 11.83 \\
\hline 23 & Korea & 83.8 & 23 & Ireland & 18.89 & 23 & Norway & 12.17 \\
\hline 24 & Italy & 86.9 & 24 & Singapore & 20.00 & 24 & Argentina & 12.22 \\
\hline
\end{tabular}


Table 1. Conitinued

\begin{tabular}{|c|c|c|c|c|c|c|c|c|}
\hline \multicolumn{3}{|c|}{$\begin{array}{l}\text { Urban particulate concentration* } \\
\text { (per city population) }\end{array}$} & \multicolumn{3}{|c|}{$\begin{array}{l}\text { Urban } \mathrm{SO}_{2} \text { concentration* } \\
\quad \text { (per city population) }\end{array}$} & \multicolumn{3}{|c|}{$\begin{array}{c}\text { Energy usage } \\
\text { (per mil. \$ GDP) }\end{array}$} \\
\hline Rank & Country & Annual mean & Rank & Country & Annual mean & Rank & Country & Bil. Btu \\
\hline 25 & Malaysia & 91.6 & 25 & Malaysia & 20.49 & 25 & Uruguay & 12.86 \\
\hline 26 & Latvia & 100.0 & 26 & Belgium & 21.02 & 26 & Greece & 12.95 \\
\hline 27 & Russia & 100.0 & 27 & Ecuador & 21.52 & 27 & Bangladesh & 13.15 \\
\hline 28 & Brazil & 106.2 & 28 & United Kingdom & 21.96 & 28 & United States & 13.41 \\
\hline 29 & Lithuania & 114.3 & 29 & South Africa & 22.37 & 29 & Sri Lanka & 13.70 \\
\hline 30 & Colombia & 120.0 & 30 & Slovak Republic & 22.66 & 30 & El Salvador & 13.75 \\
\hline 31 & Ecuador & 125.7 & 31 & Japan & 24.33 & 31 & Brazil & 14.01 \\
\hline 32 & Greece & 178.0 & 32 & Czech Republic & 27.34 & 32 & Iceland & 14.49 \\
\hline 33 & Bulgaria & 199.2 & 33 & India & 27.55 & 33 & New Zealand & 15.09 \\
\hline 34 & Philippines & 200.0 & 34 & Chile & 29.00 & 34 & Paraguay & 15.32 \\
\hline 35 & Thailand & 223.0 & 35 & Philippines & 33.00 & 35 & Estonia & 16.09 \\
\hline 36 & Costa Rica & 244.5 & 36 & Venezuela & 33.00 & 36 & Costa Rica & 16.13 \\
\hline 37 & Indonesia & 271.0 & 37 & Greece & 34.00 & 37 & Chile & 16.63 \\
\hline 38 & Guatemala & 272.3 & 38 & Hungary & 37.33 & 38 & Canada & 17.54 \\
\hline 39 & India & 277.5 & 39 & Costa Rica & 38.84 & 39 & Mexico & 17.72 \\
\hline 40 & Mexico & 279.0 & 40 & Korea & 52.41 & 40 & Korea & 17.91 \\
\hline 41 & China & 310.8 & 41 & Bulgaria & 52.45 & 41 & Bolivia & 18.41 \\
\hline \multirow[t]{8}{*}{42} & Honduras & 320.0 & 42 & Poland & 54.72 & 42 & Dominican Republic & 18.68 \\
\hline & & & 43 & Egypt & 69.00 & 43 & Panama & 18.70 \\
\hline & & & 44 & Mexico & 74.00 & 44 & Thailand & 19.29 \\
\hline & & & 45 & Brazil & 75.78 & 45 & Philippines & 19.74 \\
\hline & & & 46 & China & 97.07 & 46 & Singapore & 20.41 \\
\hline & & & 47 & Russia & 97.55 & 47 & Zimbabwe & 22.34 \\
\hline & & & & & & 48 & Malaysia & 22.88 \\
\hline & & & & & & 49 & Indonesia & 22.96 \\
\hline
\end{tabular}




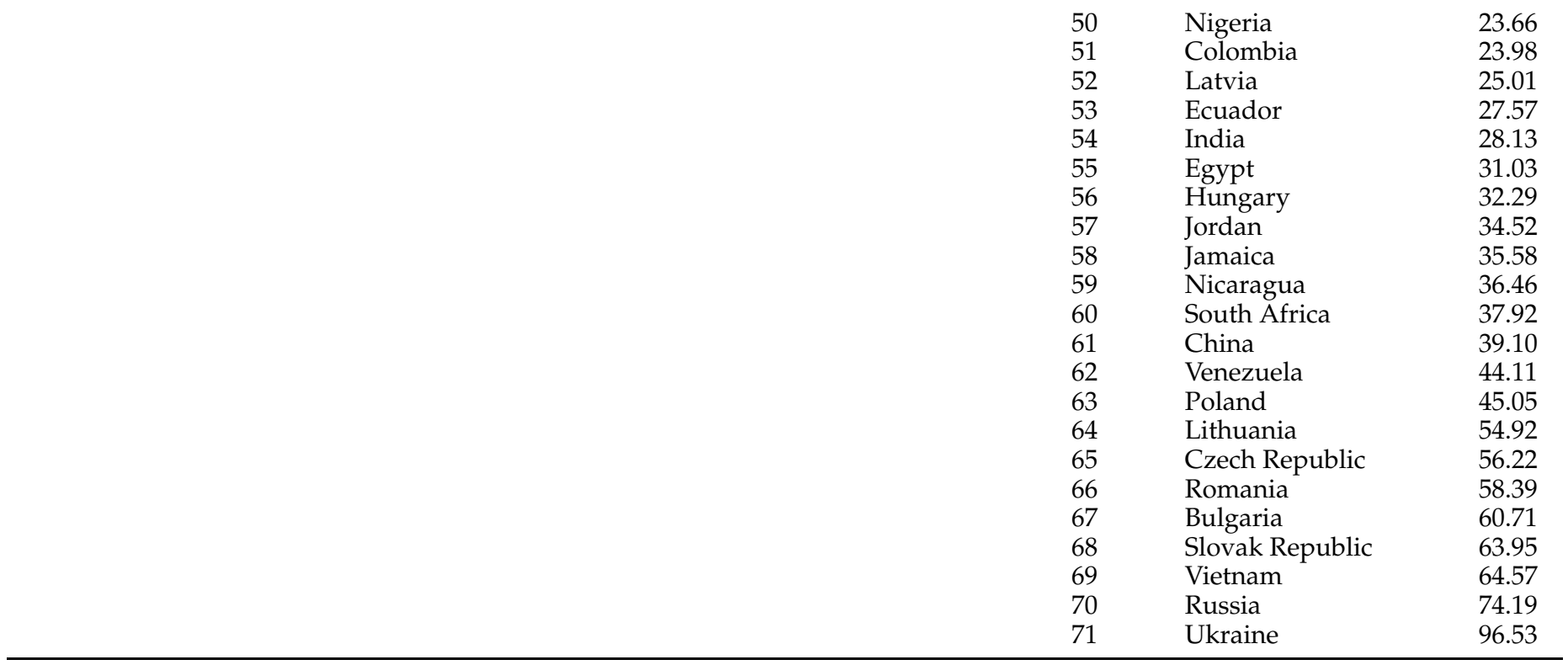

Note: ${ }^{*}$ Not all data were available for all countries. 


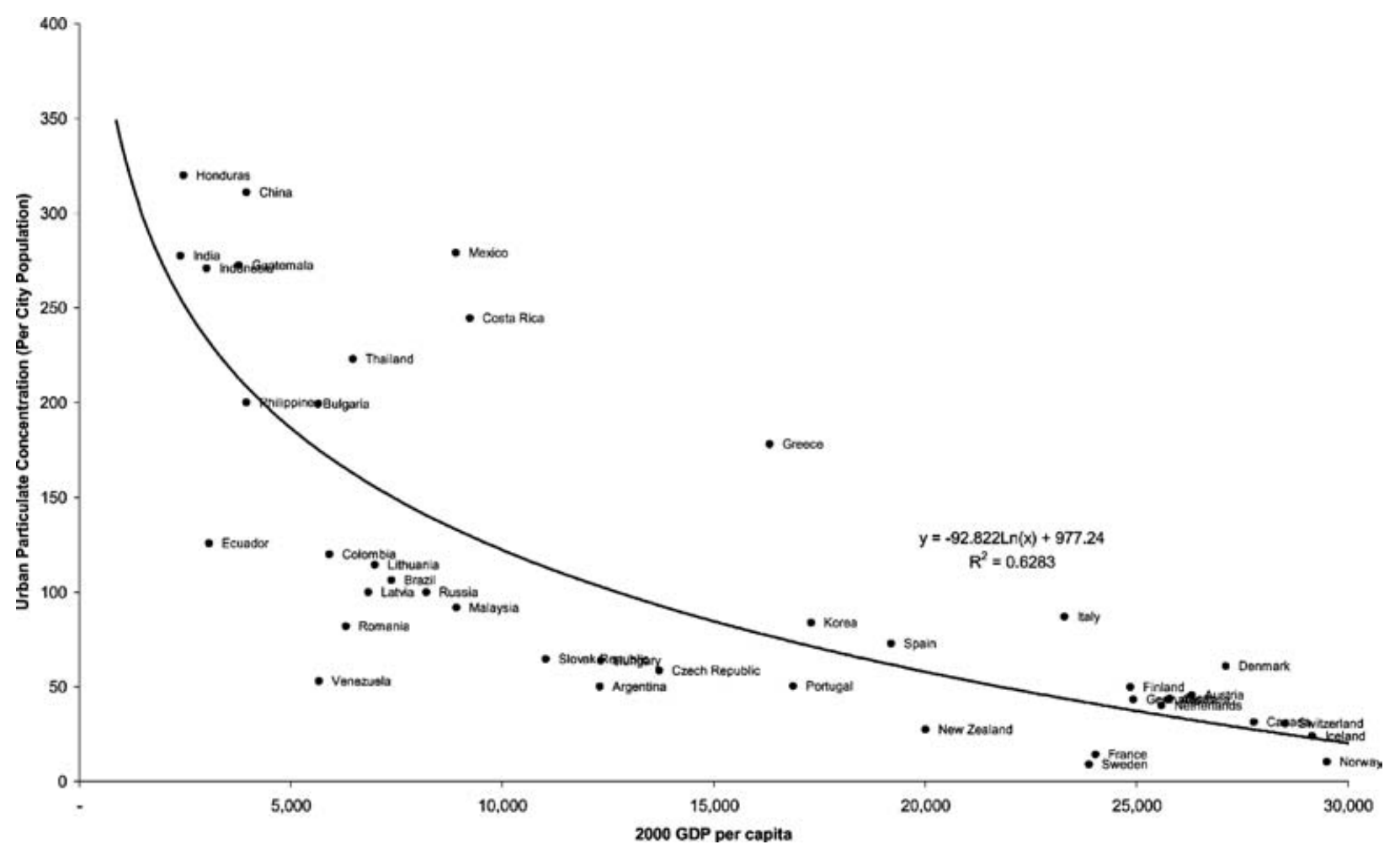

Figure 2. Relationship between urban particulate concentration and GDP per capita 


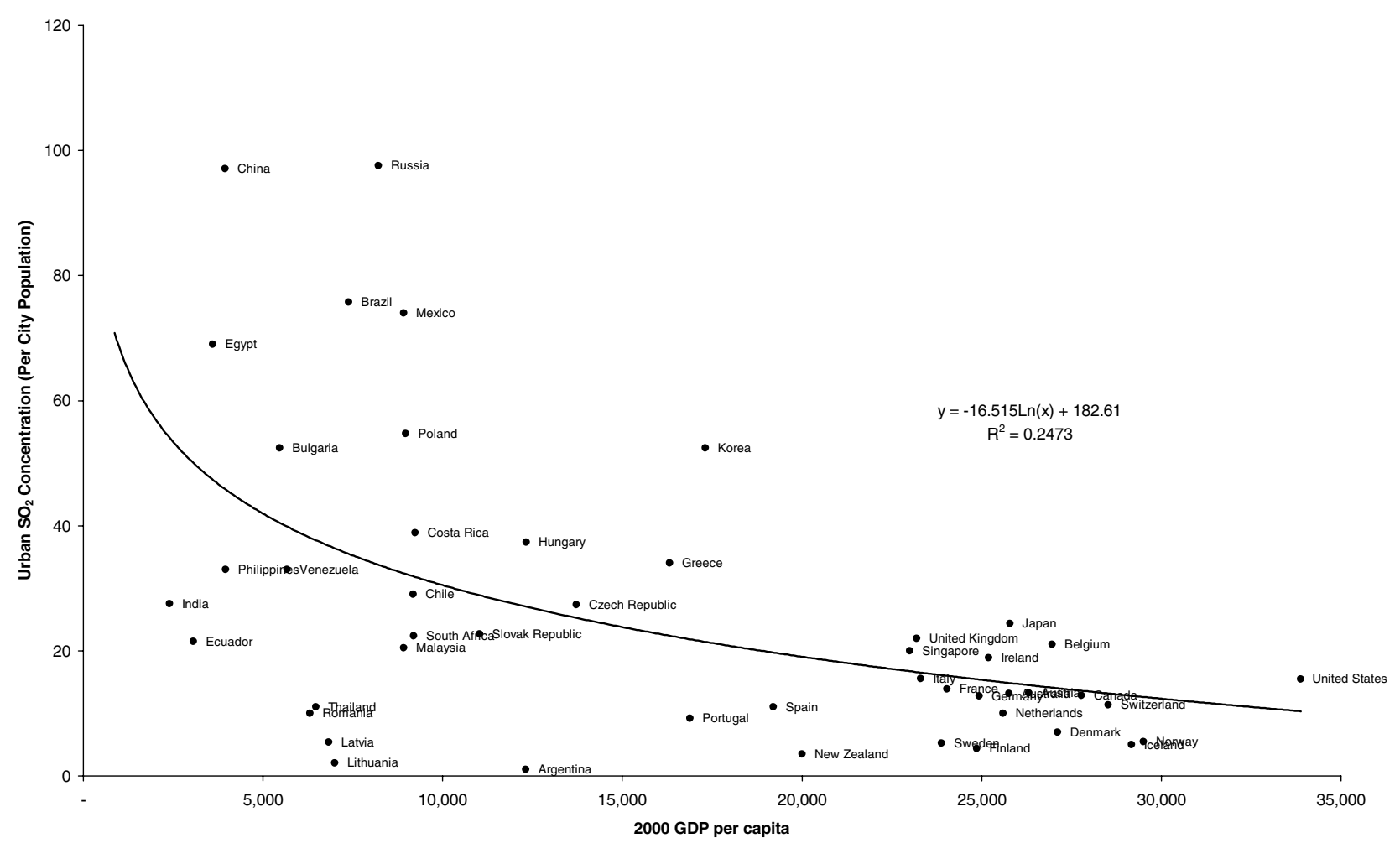

Figure 3. Relationship between urban $\mathrm{SO}_{2}$ concentration and GDP per capita 


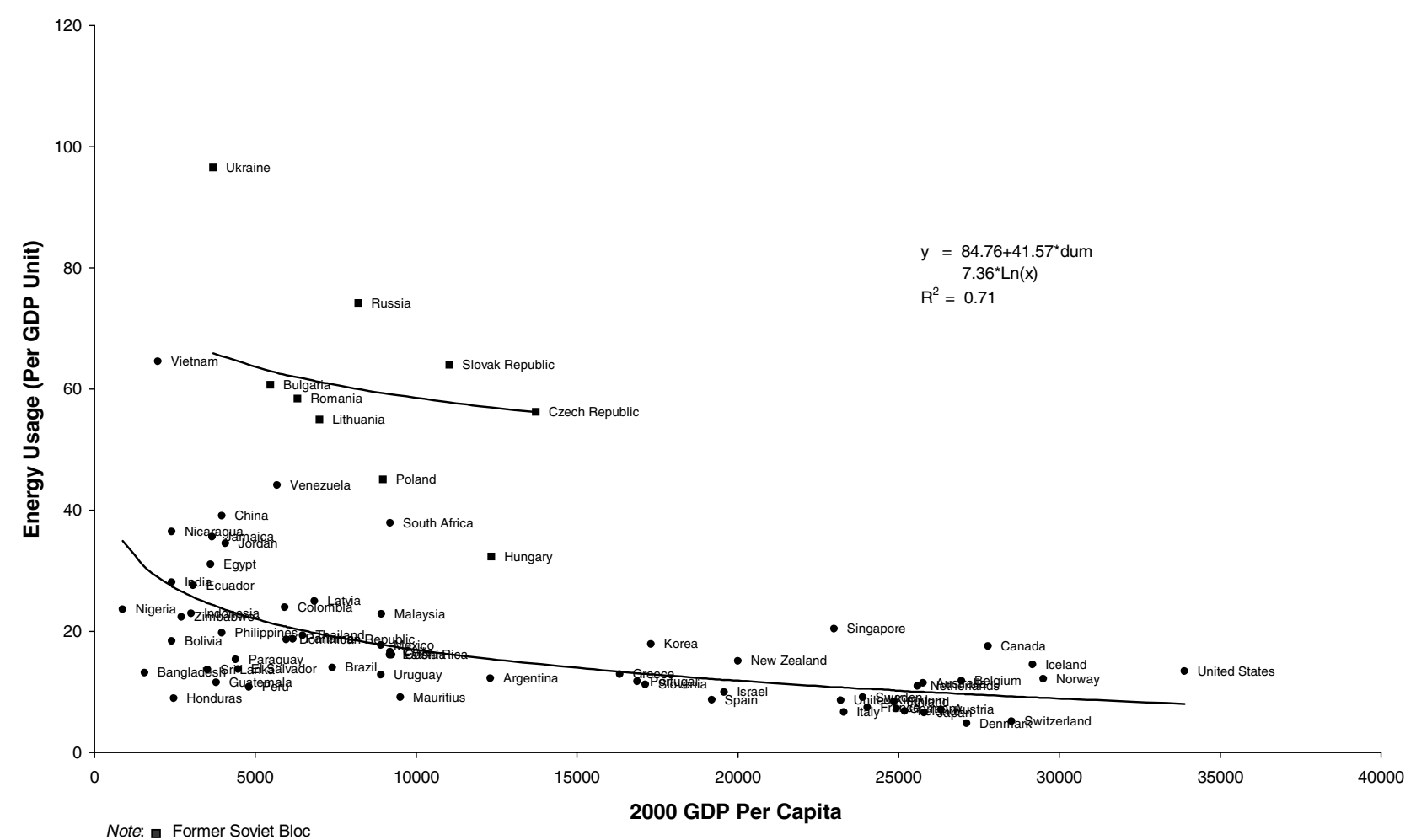

Figure 4. Relationship between energy usage and GDP per capita (log model) 
prosperous countries. This suggests that environmental performance can be substantially improved in many low-income countries, independent of the gains that come with economic development.

The regression relationship between environmental performance and GDP per capita provides an interesting perspective on how each country performs relative to its wealth. Countries above the regression line in figures 2, 3, and 4 exhibit weaker environmental results on the particular performance measure than would be expected given their level of GDP; those countries below the regression line demonstrate better-than-incomewould-suggest performance. These results (reporting residuals from the regression line) are shown in tables 2,3 , and 4.

With regard to particulate levels, Italy, Denmark, Greece, Costa Rica, Mexico, and China are notable laggards relative to income. Sweden, Argentina, Latvia, Ecuador, and Venezuela show relatively strong performance. In terms of $\mathrm{SO}_{2}$ results, Japan, Russia, Brazil, Mexico, Korea, China, and Egypt lag relative to income. Belgium and the United States are also weak performers. Finland, Sweden, Argentina, Iceland, Latvia, Lithuania, Thailand, Romania, and Ecuador perform relatively well. In energy efficiency, Denmark, Italy, Switzerland, Japan, Hungary, Poland, Honduras, and Bangladesh appear to be more energy efficient than would be expected given their level of income. The United States, Canada, Russia, South Africa, Venezuela, Ukraine, and Vietnam emerge as poor performers relative to income. As can be seen in Figure 4, the dummy variable for former Soviet bloc countries is highly significant, suggesting that countries that faced constrained energy markets and artificially low energy prices suffered a common fate of structural inefficiency.

These findings comport with established economic theory, which suggests that pollution control improves with development (World Commission on Environment and Development, 1987; Shafik and Bandyopadhyay, 1992). The data do not, however, reveal an inverted U-shaped environmental 'Kuznets curve'. A number of other studies have found such a pattern, characterized by rising emissions in the early stages of development and improving environmental performance after middle-income levels have been reached (Seldon and Song, 1994; Grossman and Krueger, 1995; Harbaugh et al., 2000). These results may be explained by the fact that our sample of countries contains relatively few countries in the 'early industrialization' stage of development, in which emissions and energy usage would be low and rising, especially for the air pollution measures.

The apparent relationship between environmental performance and level of development supports several preliminary but important policy conclusions. First, the evidence that poorer countries do less well on all three environmental performance measures supports an emphasis on alleviating poverty as a core environmental policy goal. Quite clearly, richer countries not only can, but do, invest in pollution control and other environmental improvements.

Second, the wide variations in environmental performance among countries at similar levels of economic development suggest that a country's income or development stage affects but does not alone determine environmental outcomes. Some rich countries seem to have learned how 
Table 2. Energy usage relative to expected given GDP per capita, listed by income groups

\begin{tabular}{|c|c|c|c|c|c|c|c|c|}
\hline \multicolumn{3}{|c|}{ Low income countries $(\leq \$ 6,500)$} & \multicolumn{3}{|c|}{ Middle income countries $(\$ 6,500-23,000)$} & \multicolumn{3}{|c|}{ High income countries $(\geq \$ 23,000)$} \\
\hline Rank & Country & Residual & Rank & Country & Residual & Rank & Country & Residual \\
\hline 1 & Honduras & -18.29 & 1 & Hungary & -24.70 & 1 & Denmark & -4.78 \\
\hline 2 & Bangladesh & -17.48 & 2 & Poland & -14.29 & 2 & Italy & -4.08 \\
\hline 3 & Guatemala & -12.60 & 3 & Mauritius & -8.22 & 3 & Switzerland & -4.06 \\
\hline 4 & Peru & -11.57 & 4 & Lithuania & -6.24 & 4 & Japan & -3.44 \\
\hline 5 & Nigeria & -11.28 & 5 & Brazil & -5.19 & 5 & Ireland & -3.31 \\
\hline 6 & Sri Lanka & -10.96 & 6 & Uruguay & -4.96 & 6 & France & -3.12 \\
\hline 7 & El Salvador & -9.13 & 7 & Spain & -3.44 & 7 & Germany & -2.96 \\
\hline 8 & Bolivia & -9.04 & 8 & Argentina & -3.21 & 8 & Austria & -2.75 \\
\hline 9 & Paraguay & -7.69 & 9 & Israel & -2.06 & 9 & United Kingdom & -2.18 \\
\hline 10 & Zimbabwe & -4.27 & 10 & Slovenia & -1.74 & 10 & Finland & -1.89 \\
\hline 11 & Philippines & -4.05 & 11 & Estonia & -1.51 & 11 & Sweden & -1.42 \\
\hline 12 & Romania & -3.53 & 12 & Costa Rica & -1.42 & 12 & Netherlands & 0.96 \\
\hline 13 & Indonesia & -2.84 & 13 & Portugal & -1.34 & 13 & Australia & 1.46 \\
\hline 14 & Bulgaria & -2.26 & 14 & Chile & -0.96 & 14 & Belgium & 2.16 \\
\hline 15 & Dominican Republic & -2.09 & 15 & Greece & -0.41 & 15 & Norway & 3.17 \\
\hline 16 & Panama & -1.82 & 16 & Mexico & -0.09 & 16 & Iceland & 5.41 \\
\hline 17 & Thailand & -0.88 & 17 & Czech Republic & 0.02 & 17 & United States & 5.43 \\
\hline 18 & India & 0.67 & 18 & New Zealand & 3.24 & 18 & Canada & 8.10 \\
\hline 19 & Ecuador & 1.90 & 19 & Korea & 4.98 & & & \\
\hline 20 & Colombia & 3.17 & 20 & Malaysia & 5.08 & & & \\
\hline 21 & Egypt & 6.55 & 21 & Latvia & 5.25 & & & \\
\hline 22 & Nicaragua & 8.98 & 22 & Slovak Republic & 6.14 & & & \\
\hline 23 & Jordan & 10.96 & 23 & Singapore & 9.58 & & & \\
\hline 24 & Jamaica & 11.21 & 24 & Russia & 14.20 & & & \\
\hline 25 & China & 15.30 & 25 & South Africa & 20.33 & & & \\
\hline 26 & Venezuela & 22.98 & & & & & & \\
\hline 27 & Ukraine & 30.66 & & & & & & \\
\hline 28 & Vietnam & 35.66 & & & & & & \\
\hline
\end{tabular}


Table 3. Urban particulate concentration relative to expected given GDP per capita, listed by income groups*

\begin{tabular}{|c|c|c|c|c|c|c|c|c|}
\hline \multicolumn{3}{|c|}{ Low income countries $(\leq \$ 6,500)$} & \multicolumn{3}{|c|}{ Middle income countries $(\$ 6,500-23,000)$} & \multicolumn{3}{|c|}{ High income countries $(\geq \$ 23,000)$} \\
\hline Rank & Country & Residual & Rank & Country & Residual & Rank & Country & Residual \\
\hline 1 & Venezuela & -121.87 & 1 & Latvia & -57.59 & 1 & Sweden & -32.50 \\
\hline 2 & Ecuador & -106.27 & 2 & Argentina & -52.99 & 2 & France & -26.77 \\
\hline 3 & Romania & -83.06 & 3 & Slovak Republic & -48.69 & 3 & Norway & -11.65 \\
\hline 4 & Colombia & -50.93 & 4 & Brazil & -44.20 & 4 & Iceland & 1.05 \\
\hline 5 & Philippines & -8.40 & 5 & Malaysia & -41.31 & 5 & Canada & 3.80 \\
\hline 6 & Bulgaria & 20.92 & 6 & Lithuania & -41.17 & 6 & Netherlands & 4.93 \\
\hline 7 & India & 22.78 & 7 & Russia & -40.59 & 7 & Switzerland & 5.62 \\
\hline 8 & Indonesia & 37.35 & 8 & Hungary & -39.10 & 8 & Germany & 5.75 \\
\hline 9 & Guatemala & 59.80 & 9 & Czech Republic & -34.57 & 9 & Australia & 8.73 \\
\hline 10 & Thailand & 60.26 & 10 & New Zealand & -30.61 & 10 & Japan & 9.28 \\
\hline 11 & Honduras & 67.85 & 11 & Portugal & -23.31 & 11 & Finland & 12.13 \\
\hline 12 & China & 102.36 & 12 & Spain & 10.93 & 12 & Austria & 13.20 \\
\hline & & & 13 & Korea & 12.41 & 13 & Denmark & 31.29 \\
\hline & & & 14 & Greece & 101.19 & 14 & Italy & 43.13 \\
\hline & & & 15 & Costa Rica & 114.79 & & & \\
\hline & & & 16 & Mexico & 146.02 & & & \\
\hline
\end{tabular}

Note: ${ }^{*}$ Not all data were available for all countries. 
Table 4. Urban $\mathrm{SO}_{2}$ concentration relative to expected given GDP per capita, listed by income groups*

\begin{tabular}{|c|c|c|c|c|c|c|c|c|}
\hline \multicolumn{3}{|c|}{ Low income countries $(\leq \$ 6,500)$} & \multicolumn{3}{|c|}{ Middle income countries $(\$ 6,500-23,000)$} & \multicolumn{3}{|c|}{ High income countries $(\geq \$ 23,000)$} \\
\hline Rank & Country & Residual & Rank & Country & Residual & Rank & Country & Residual \\
\hline 1 & Ecuador & -28.49 & 1 & Lithuania & -34.29 & 1 & Finland & -11.07 \\
\hline 2 & Romania & -28.10 & 2 & Latvia & -31.41 & 2 & Sweden & -10.89 \\
\hline 3 & Thailand & -26.69 & 3 & Argentina & -26.04 & 3 & Iceland & -7.81 \\
\hline 4 & India & -26.49 & 4 & New Zealand & -15.54 & 4 & Norway & -7.16 \\
\hline 5 & Philippines & -12.81 & 5 & Portugal & -12.63 & 5 & Denmark & -7.02 \\
\hline 6 & Venezuela & -6.84 & 6 & Malaysia & -11.88 & 6 & Netherlands & -4.97 \\
\hline 7 & Bulgaria & 11.99 & 7 & South Africa & -9.52 & 7 & Germany & -2.60 \\
\hline 8 & Egypt & 21.64 & 8 & Spain & -8.72 & 8 & France & -2.12 \\
\hline 9 & China & 51.25 & 9 & Slovak Republic & -6.21 & 9 & Switzerland & -1.85 \\
\hline & & & 10 & Chile & -2.89 & 10 & Australia & -1.70 \\
\hline & & & 11 & Czech Republic & 2.07 & 11 & Austria & -1.31 \\
\hline & & & 12 & Singapore & 3.26 & 12 & Italy & -0.97 \\
\hline & & & 13 & Costa Rica & 7.03 & 13 & Canada & -0.75 \\
\hline & & & 14 & Hungary & 10.30 & 14 & Ireland & 3.67 \\
\hline & & & 15 & Greece & 11.60 & 15 & United States & 5.09 \\
\hline & & & 16 & Poland & 22.43 & 16 & United Kingdom & 5.37 \\
\hline & & & 17 & Korea & 30.98 & 17 & Belgium & 6.91 \\
\hline & & & 18 & Brazil & 40.29 & 18 & Japan & 9.49 \\
\hline & & & 19 & Mexico & 41.61 & & & \\
\hline & & & 20 & Russia & 63.80 & & & \\
\hline
\end{tabular}

Note: ${ }^{*}$ Not all data were available for all countries. 
to advance environmental quality ahead of their economic progress; others have not. Similarly, some developing countries appear to have achieved strong environmental performance relative to their level of development, while other countries seem to be unduly sacrificing the environment in the pursuit of economic growth. In any case, it appears that at every income level, there are important environmental choices and broader policy decisions to be made - and that some countries are systematically choosing well, while others are not. This conclusion represents an important step beyond the existing EKC literature.

Third, income-driven improvements in environmental performance seem to emerge most quickly for the most localized problem (particulates) and least rapidly with regard to energy impacts, in which a significant element of harm (notably greenhouse gas emissions from fossil fuel burning) spreads widely over space and time. Intermediate results occur for the $\left(\mathrm{SO}_{2}\right)$ variable with harms that arise on an intermediate spatial and temporal scale. This pattern tracks the theoretical prediction that the geographic and temporal spread of an environmental issue represents critical policy variables. Where harms have a significant transboundary or inter-temporal dimension, they constitute 'super externalities', which generate special collective action problems that often prove difficult to address (Dua and Esty, 1997).

\section{Determinants of environmental performance}

The conclusion that income levels do not fully explain the variance in environmental performance leads us to our central inquiry: what are the other determinants of environmental results? To answer this question, we assemble data on policy variables that could determine environmental outcome, building on theoretical work in the economic, legal, regulatory, and environmental domains. As noted above, the independent variables in the model consist of two broad groups: (1) measures of a nation's environmental regulatory regime and (2) measures of its economic and legal context. ${ }^{10}$

The regulatory regime can be divided into a number of elements:

- stringency of pollution standards

- sophistication of the regulatory structure

- availability of relevant policy-making information

- subsidization of natural resources

- strictness of regulatory enforcement

- capacity of a country's environmental institutions

The 'stringency of standards' category includes measures (drawn from the GCR survey) of the perceived rigor of a nation's regulations on air pollution, water pollution, toxic waste, and chemicals. We expect a negative relationship between each of the measures of regulatory stringency and our dependent variables, since more rigorous standards should lead to lower levels of urban particulates, lower $\mathrm{SO}_{2}$ concentrations, and lower energy usage per unit of GDP.

${ }^{10}$ The full list of variables used in the analysis along with their definitions and sources are given in appendix A. 
The 'regulatory structure' category seeks to measure the degree to which a nation's environmental regulations are flexible, clear, consistent, structured to aid competitiveness, and designed to promote cooperative versus adversarial business-government relations. In each case, we anticipate a negative relationship between these variables and our measures of environmental performance because a more refined and sophisticated regulatory structure is expected to produce less pollution and more efficient energy usage.

The 'information' category attempts to measure the degree to which a nation has the data needed for policy making and to support enforcement of environmental regulations. There are no direct measures of the quality of the information underlying each country's environmental regime. We therefore rely on four proxy variables drawn from the ESI data set: (1) the degree to which a country collects data in the 65 categories tracked by the ESI analysis; (2) the extent to which a nation generates sustainable development information and the existence of plans to support national environmental decision making (as called for in the Rio Earth Summit's Agenda 21 process); (3) the prevalence of guidelines for sectoral environmental impact assessments; and (4) the breadth of environmental action plans. All of these information indicators are relatively crude, but provide some basis for gauging whether a nation seeks to make environmental judgments on an analytically rigorous basis. We expect a negative relationship between these information variables and our environmental performance measures, such that better information leads to less pollution and improved energy efficiency.

The 'subsidies' measure derives from the GCR survey data the extent to which a country subsidizes energy and other materials. Where price signals are distorted we expect to see greater inefficiency and higher levels of pollution. We thus anticipate a positive relationship between the level of subsidies and particulate levels, $\mathrm{SO}_{2}$ concentrations, and energy usage.

The 'strictness of enforcement' measures are also drawn from the GCR survey. The first measure gauges how aggressively a nation's domestic environmental regulations are enforced, and the second provides an indicator of the depth of a country's commitment to treaty requirements and other international environmental obligations. We expect a negative relationship between these measures of enforcement rigor and our dependent variables, as those countries which take environmental regulations seriously (whether domestic or international) should experience better pollution control and energy usage results.

The final regulatory regime category, 'institutional capacity', seeks to measure the degree to which inter-governmental organizations and nongovernmental entities (environmental groups, community organizations, business associations, and other elements of civil society) reinforce a country's environmental efforts. The mechanisms for such reinforcement are diverse (Esty, 1998). In some cases, these entities directly undertake environmental activities and thus substitute for governmental action. Environmental groups, for instance, may identify harms, highlight issues that demand attention, gather and analyze data, or throw a spotlight on poor environmental performance. NGOs may also indirectly strengthen a society's capacity for pollution control by providing environmental education to the public or technical assistance to polluters or government 
agencies. Of course, such entities may play counter-productive roles, unnecessarily increasing environmental costs. Such negative outcomes should be anticipated if they pursue extreme positions, distort the decisionmaking process, or utilize adversarial and divisive policy approaches.

Our capacity to measure institutional capacity is limited. The variables in this category are therefore somewhat crude proxies. We use data on the number of entities (scaled by population) that participate in the World Conservation Union (IUCN), an umbrella organization of environmental NGOs and research centers. We also draw on ESI data that provide a measure of the breadth of a country's engagement with inter-governmental environmental bodies. A third institutional quality variable comes from the GCR survey data on the extent to which a nation's companies utilize the ISO 14000 certification process for environmental management. We expect a negative relationship between these measures and our dependent variables.

\section{Economic and legal context}

The second broad group of independent variables tracks potentially significant dimensions of a country's economic and legal context. Our analysis in this regard draws on a growing theoretical literature that focuses on 'governance' (Annan, 1997; Sachs, 1998), which suggests that a country's underlying political, legal, and economic structures may contribute as much to environmental protection as the details of its regulatory regime (Esty, 1997; Panayotou, 1997; Esty and Porter, 2000).

Under the economic and legal context, there are two categories of variables. First, we analyze what we call administrative infrastructure. In this category, we assemble data on civil and political liberties drawn from the ESI and measures from the GCR survey of public sector competence, the degree of governmental favoritism, the extent of private property protection, the independence of the judiciary, demands for irregular payments as a price for doing business, burdensome regulations, corruption, the extent of the rule of law, and the degree to which new governments honor the obligations of prior administrations. For each of these variables, we anticipate a negative relationship vis-à-vis our environmental performance measures.

The second group of variables under legal and economic context addresses various aspects of a country's scientific and technical capacity. It is again hard to measure scientific sophistication and analytic rigor directly, so we rely upon a series of proxies, including data on the number of scientists and engineers (scaled by population) in each country and survey data that provide a gauge of a country's technological development, intellectual property protection, research and development spending, willingness to absorb new technologies, business commitment to innovation, the strength of its scientific community, the degree to which foreign technology is commonly licensed, and governmental focus on technology development and innovation. We expect each of these measures of scientific and technical capacity to be negatively correlated with environmental impacts, as greater analytic strength should lead to better environmental performance.

As we have tried to make clear, the independent variables are far from perfect measures of the potential determinants of national environmental outcomes. These variables - drawn from data collected by a variety 
of international bodies such as the World Bank and the World Health Organization - are, however, the best ones currently available. Despite the limitations, these data allow us to begin to identify empirically the determinants of a nation's success in controlling pollution and improving resource productivity.

\section{Statistical methodology}

Our analytic approach unfolds in several stages. First, we use bilateral regressions (tables 5, 6, and 7) to explore whether there is a statistically significant relationship between each independent variable and energy usage, urban particulate levels, and $\mathrm{SO}_{2}$ concentrations. Because our sample sizes of 40-70 countries are relatively small in comparison to the number of explanatory variables, we have limited degrees of freedom. Moreover, the fact that many of our independent variables are highly correlated limits our ability to use multiple regression techniques to examine the joint influence of the variables (Rawlings et al., 1998). Instead, as a second stage of analysis, we 'roll up' the significant independent variable in each category into a subindex using common factor analysis. Then, we regress these sub-indices against the dependent variables. ${ }^{11}$ Finally, the statistically significant subindices are rolled up into an overall environmental regulatory regime index (ERRI) and an overall economic and legal context index (ELCI).

In light of the significant association between per capita GDP and environmental performance, we analyze performance relative to a peer group of countries defined by income level. We regress ERRI against GDP per capita (graphed in figure 6) and calculate the residuals (distance above or below the regression line) for each country (table 9). This provides a way of analyzing how each country's environmental regime performs against expectations established by its income level.

\section{Results for individual measures and indexes}

The bilateral regression results are shown in tables 5, 6, and 7. ${ }^{12}$ As table 5 highlights, a large number of the independent variables show a statistically significant relationship with energy usage, with the expected negative sign and a reasonable degree of explained variance. All of the elements of the regulatory stringency category show particular significance, as do the enforcement variables. Most of the regulatory structure measures also prove

${ }^{11}$ In developing the category sub-indices, we use only those variables that appear appropriately grouped, based on eigen value analysis, as shown in the factor analysis results given in appendix $\mathrm{B}$. Thus, in developing the regulatory stringency sub-index, we drop the overall regulation measure. The sectoral EIA guidelines measure and the environmental strategies and action plans measure drop out of the information sub-index. The measure of civil liberties, public sector competence, irregular payments, and regulatory burden are all dropped from the administrative infrastructure sub-index. And the scientists/engineers, licensing of foreign technology, and business innovation measures fall out of the technical capacity sub-index. Appendix B reports the percentage of covariance illustrated by the first factor and the first factor coefficient for each index variable.

${ }^{12}$ GMM estimation instead of OLS estimation is used due to the presence of heteroscedeasticity. 
Table 5. Bilateral regressions: energy usage*

\begin{tabular}{|c|c|c|c|c|}
\hline & \multicolumn{4}{|c|}{$\begin{array}{c}2001 \\
\text { Dependent variable: energy } \\
\text { usage (per unit GDP) }\end{array}$} \\
\hline & $(\beta)$ & $R^{2}$ & Sig. & $d f$ \\
\hline Environmental Regulatory Regime Index & -5.281 & 0.67 & 0.000 & 68 \\
\hline Stringency Sub-Index & -5.632 & 0.68 & 0.000 & 68 \\
\hline Air Regulation & -4.044 & 0.69 & 0.000 & 68 \\
\hline Water Regulation & -3.859 & 0.68 & 0.000 & 68 \\
\hline Toxic Waste Regulation & -3.576 & 0.67 & 0.000 & 68 \\
\hline Chemical Regulation & -3.902 & 0.68 & 0.000 & 68 \\
\hline Overall Regulation & -3.917 & 0.67 & 0.000 & 68 \\
\hline Regulatory Structure Sub-Index & -4.480 & 0.64 & 0.002 & 68 \\
\hline Options for Compliance & -4.005 & 0.60 & 0.102 & 68 \\
\hline Confusing and Changing & -4.982 & 0.65 & 0.001 & 68 \\
\hline Early or Late & -4.058 & 0.67 & 0.000 & 68 \\
\hline Compliance Hurts or Helps Competitiveness & -6.094 & 0.62 & 0.016 & 68 \\
\hline Regulation Adversarial or Cooperative & -6.355 & 0.63 & 0.007 & 68 \\
\hline Information Sub-Index & -2.507 & 0.61 & 0.081 & 68 \\
\hline ESI-Variables \%-available & -0.271 & 0.62 & 0.020 & 68 \\
\hline Sustainable Development Info & -1.009 & 0.58 & 0.764 & 41 \\
\hline Number of Sectoral EIA Guidelines & 0.041 & 0.59 & 0.923 & 68 \\
\hline $\begin{array}{l}\text { Number of Environmental Strategies \& } \\
\text { Action Plans }\end{array}$ & -0.197 & 0.59 & 0.815 & 68 \\
\hline \multicolumn{5}{|l|}{ Subsidies Sub-Index } \\
\hline Government Subsidies & 7.065 & 0.66 & 0.000 & 68 \\
\hline Regulatory Enforcement Sub-Index & -4.466 & 0.65 & 0.001 & 68 \\
\hline Enforcement & -3.890 & 0.65 & 0.001 & 68 \\
\hline International Agreements & -3.976 & 0.64 & 0.002 & 68 \\
\hline Environmental Institutions Sub-Index & -4.740 & 0.65 & 0.001 & 68 \\
\hline IUCN & -1.392 & 0.60 & 0.300 & 68 \\
\hline Memberships & -0.699 & 0.65 & 0.001 & 67 \\
\hline Prevalence of ISO 14000 & -3.994 & 0.63 & 0.011 & 68 \\
\hline Economic and Legal Context Index & -4.836 & 0.65 & 0.001 & 68 \\
\hline Administrative Infrastructure Quality Index & -5.647 & 0.68 & 0.000 & 68 \\
\hline Civil Liberties & -5.190 & 0.75 & 0.000 & 68 \\
\hline Public Sector Competence & -2.383 & 0.59 & 0.333 & 68 \\
\hline Gov't Favor Private Sector Firms & -4.200 & 0.64 & 0.003 & 68 \\
\hline Property Rights & -4.756 & 0.71 & 0.000 & 68 \\
\hline Independent Judiciary & -3.426 & 0.66 & 0.000 & 68 \\
\hline Irregular Payments & -4.973 & 0.68 & 0.000 & 68 \\
\hline Legal Framework & -3.880 & 0.66 & 0.000 & 68 \\
\hline Regulatory Burden & -5.144 & 0.63 & 0.006 & 68 \\
\hline Level of Administrative Corruption & -5.695 & 0.69 & 0.000 & 68 \\
\hline Honoring of Policies through Gov. Transition & -4.558 & 0.65 & 0.001 & 68 \\
\hline Scientific and Research Infrastructure Index & -3.788 & 0.63 & 0.008 & 68 \\
\hline Scientists and Engineers & -0.003 & 0.64 & 0.004 & 64 \\
\hline Technology Position & -3.636 & 0.66 & 0.000 & 68 \\
\hline Institutions & -3.341 & 0.62 & 0.018 & 68 \\
\hline Licensing of Foreign Technology & -3.692 & 0.61 & 0.055 & 68 \\
\hline Company R \& D Spending & -4.207 & 0.64 & 0.002 & 68 \\
\hline Willingness to Absorb New Technology & -3.803 & 0.62 & 0.033 & 68 \\
\hline Importance of Innovation to Revenue & -6.158 & 0.62 & 0.020 & 68 \\
\hline Gov't Purchase Decisions for Tech. Products & -2.962 & 0.60 & 0.160 & 68 \\
\hline
\end{tabular}

Note: * Refer to appendix A for definitions of variables. 
to be highly significant. These categories of variables account for the highest amount of explained variance. The subsidies variable is highly significant and has the expected positive sign. This result suggests, consistent with economic theory, that mispriced resources will be inefficiently used and that subsidies represent a major policy error.

The information and institutional capacity measures perform less well. In the information category, one variable, percentage of ESI variables available, emerges as significant, while the other three measures do not. In the institutional category, IUCN membership fails to show significance, while the other two measures are significant.

Among the economic and legal context variables, all but one, public sector competence, emerge as highly significant with the expected negative sign. The new variables measuring corruption and whether new governments honor the commitments of prior administrations prove to be statistically significant. In the scientific and technical capacity category, all of the variables except one, government commitment to technology development and innovation, show a reasonable degree of significance and the expected negative sign.

All of the sub-indices are highly significant in explaining energy usage, have the expected negative sign, and account for substantial explained variance. ${ }^{13}$ The ERRI and ELCI register similarly high levels of significance, with the expected negative signs and a substantial degree of explained variance.

Although preliminary, the latter results provide some empirical support for the hypothesis that a nation's underlying economic and legal structure may be as important to environmental success as the specific details of its environmental regulatory regime. This conclusion argues for more attention to setting development priorities and to targeting development assistance for structural 'fundamentals', such as eliminating corruption and building functioning market economies, and for 'governance' issues, such as strengthening the rule of law and developing mechanisms to protect property rights.

The ERRI and the ELCI prove to be highly correlated and show similar levels of significance and explained variance. Hence it appears that environmental regulation and the overall economic and legal context generally improve in parallel. The high correlation between the two indices (as shown in figure 5) means that their independent effects could not be distinguished statistically.

Table 6 presents the second set of bilateral regressions for urban particulate concentrations. Again, the vast majority of variables are significant with the expected sign and account for a reasonable degree of explained variance. All of the measures of regulatory stringency and structure are highly significant, with the stringency variables accounting for the greatest level of explained variance. The subsidies measure emerges as highly significant, has the anticipated positive sign, and accounts for a reasonable degree of explained variance.

In the information category, two variables show significance with the expected negative sign, but they do not account for as high a degree of

${ }^{13}$ To build the sub-indices and indexes, we employ only the statistically significant variables. 


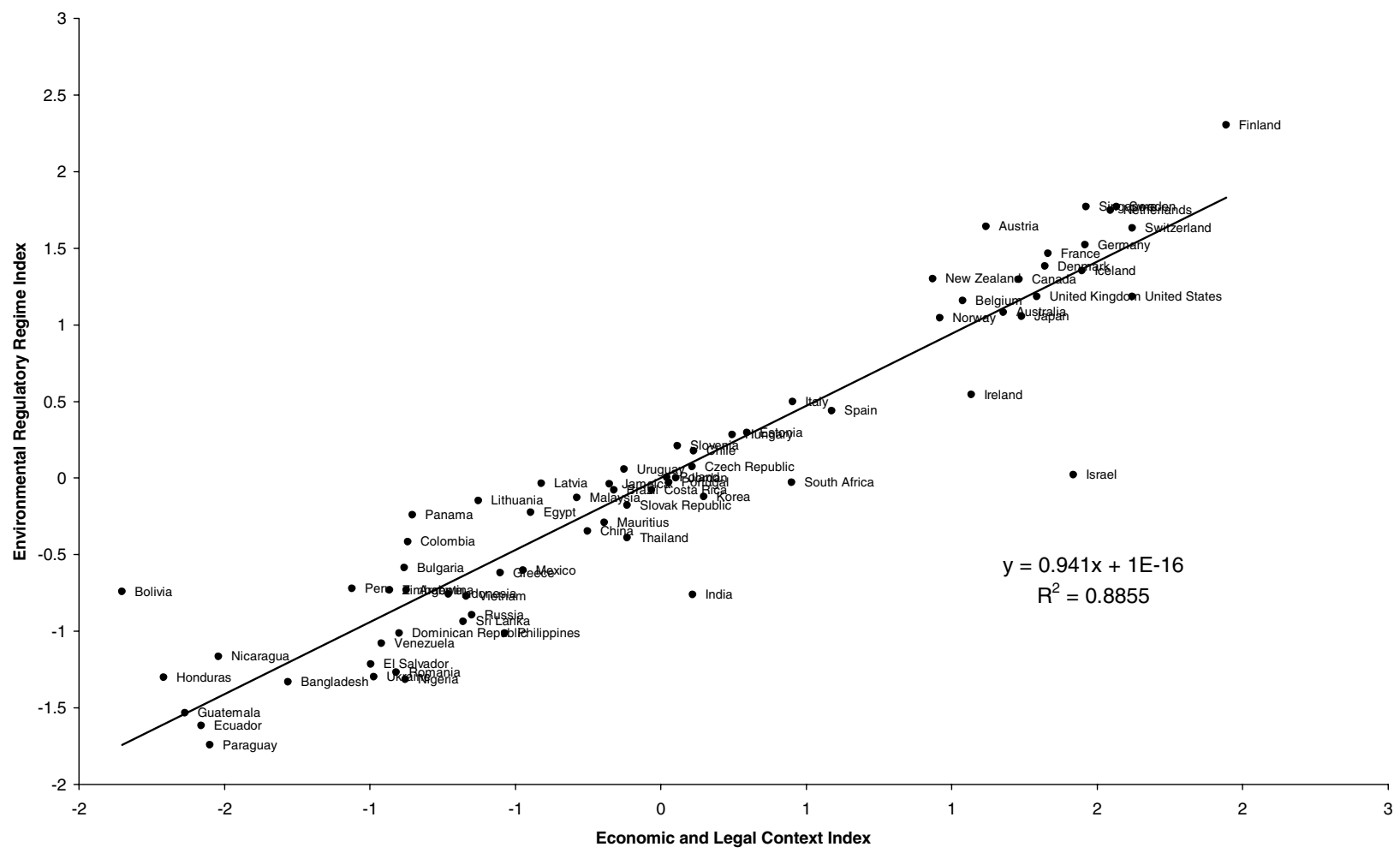

Figure 5. Relationship between the environmental regulatory regime index and economic and legal context index 
Table 6. Bilateral regressions: urban particulates*

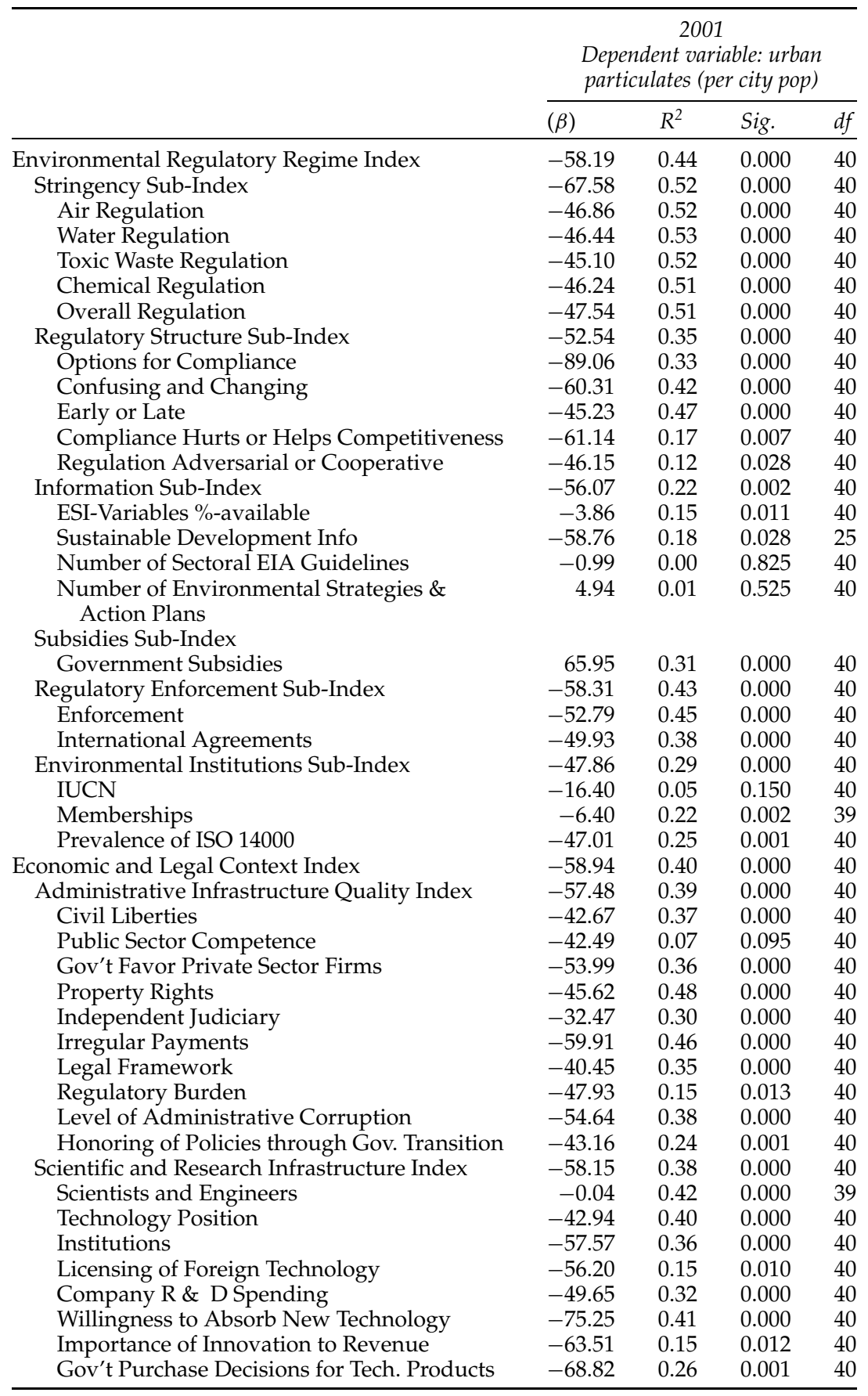

Note: * Refer to appendix A for definitions of variables. 
explained variance. In the institutional reinforcement category, the number of IUCN memberships is again not significant, while the other two variables, participation in inter-governmental environmental bodies and corporate participation in environmental management systems, emerge as highly significant.

The regulatory stringency, regulatory structure, information enforcement, and institutional sub-indices are all highly significant, with the expected negative sign, as is the cumulative ERRI. Across all of these subindices, however, the degree of explained variance appears to be somewhat lower in the urban particulate regressions than in the energy usage ones. Two of the sub-indices - information foundations and institutional reinforcement - perform notably less well than the others. This result may arise from the fact that these variables are imperfect proxies or that information and institutions play more mixed roles.

All of the variables in the economic and social context regression emerge as significant in the urban particulates analysis. All have the expected negative sign, with many accounting for a substantial degree of explained variance. The administrative infrastructure and technical capacity subindices both show very high levels of significance, the expected negative sign, and a high degree of explained variance. The ELCI similarly emerges as highly significant. It accounts for almost as much explained variance as the ERRI. However, both the ERRI and the ELCI explain a somewhat smaller proportion of variations in urban particulate concentrations than energy usage. Again, the independent effects of ERRI and ELCI could not be distinguished statistically.

The $\mathrm{SO}_{2}$ regression results are presented in table 7 . Most of the independent variables are once again significant with the expected negative sign. The degree of explained variance is, however, generally much lower for $\mathrm{SO}_{2}$ than for either energy usage or particulate concentrations. This finding may reflect the fact that the benefits of $\mathrm{SO}_{2}$ control (reduced acid rain) accrue downwind - frequently beyond the territorial boundaries of the jurisdiction undertaking regulatory action. Thus, from a cost-benefit perspective, the regulating entity has less to gain from $\mathrm{SO}_{2}$ abatement than from the control of particulates or from investments in energy efficiency, both of which provide a substantial degree of localized benefits.

The subsidies measure again shows a high level of significance and the expected positive sign, but accounts for a lower amount of variance than the other measures of pollution. In the information category, three of the four measures are not statistically significant. The looser fit may suggest that even a well-informed government that is serious about environmental protection has less of an incentive to address $\mathrm{SO}_{2}$, given its geographic dispersion, than it does to tackle other more localized issues.

All of the environmental regulatory regime sub-indices are significant and have the expected negative sign in the $\mathrm{SO}_{2}$ regressions, but only the regulatory stringency sub-index accounts for a reasonable degree of explained variance. ERRI once again proves to be highly significant, although the degree of explained variance is not high. As a general matter, the regression fit for $\mathrm{SO}_{2}$ appears weaker than for particulates or for energy usage, perhaps reflecting the more limited regulatory pay-offs noted above. 
Table 7. Bilateral regressions: urban $\mathrm{SO}_{2}$ concentration*

\begin{tabular}{|c|c|c|c|c|}
\hline & \multicolumn{4}{|c|}{$\begin{array}{c}2001 \\
\text { Dependent variable: urban } \\
\mathrm{SO}_{2} \text { (per city pop) }\end{array}$} \\
\hline & $(\beta)$ & $R^{2}$ & Sig. & $d f$ \\
\hline Environmental Regulatory Regime Index & -11.351 & 0.21 & 0.001 & 45 \\
\hline Stringency Sub-Index & -13.857 & 0.28 & 0.000 & 45 \\
\hline Air Regulation & -9.407 & 0.27 & 0.000 & 45 \\
\hline Water Regulation & -9.592 & 0.28 & 0.000 & 45 \\
\hline Toxic Waste Regulation & -9.283 & 0.27 & 0.000 & 45 \\
\hline Chemical Regulation & -9.538 & 0.27 & 0.000 & 45 \\
\hline Overall Regulation & -9.839 & 0.27 & 0.000 & 45 \\
\hline Regulatory Structure Sub-Index & -9.686 & 0.16 & 0.005 & 45 \\
\hline Options for Compliance & -9.312 & 0.05 & 0.130 & 45 \\
\hline Confusing and Changing & -11.905 & 0.20 & 0.002 & 45 \\
\hline Early or Late & -10.105 & 0.28 & 0.000 & 45 \\
\hline Compliance Hurts or Helps Competitiveness & -11.584 & 0.09 & 0.038 & 45 \\
\hline Regulation Adversarial or Cooperative & -11.128 & 0.11 & 0.022 & 45 \\
\hline Information Sub-Index & -10.206 & 0.10 & 0.029 & 45 \\
\hline ESI-Variables \%-available & 0.207 & 0.00 & 0.662 & 45 \\
\hline Sustainable Development Info & -21.624 & 0.25 & 0.004 & 29 \\
\hline Number of Sectoral EIA Guidelines & -0.708 & 0.01 & 0.464 & 45 \\
\hline $\begin{array}{l}\text { Number of Environmental Strategies \& } \\
\text { Action Plans }\end{array}$ & 0.722 & 0.00 & 0.732 & 45 \\
\hline \multicolumn{5}{|l|}{ Subsidies Sub-Index } \\
\hline Government Subsidies & 12.301 & 0.15 & 0.008 & 45 \\
\hline Regulatory Enforcement Sub-Index & -10.989 & 0.18 & 0.003 & 45 \\
\hline Enforcement & -8.960 & 0.17 & 0.004 & 45 \\
\hline International Agreements & -10.221 & 0.19 & 0.003 & 45 \\
\hline Environmental Institutions Sub-Index & -6.921 & 0.08 & 0.053 & 45 \\
\hline IUCN & -6.270 & 0.10 & 0.030 & 45 \\
\hline Memberships & -0.684 & 0.04 & 0.194 & 44 \\
\hline Prevalence of ISO 14000 & -8.027 & 0.10 & 0.034 & 45 \\
\hline Economic and Legal Context Index & -11.738 & 0.19 & 0.002 & 45 \\
\hline Administrative Infrastructure Quality Index & -12.815 & 0.23 & 0.001 & 45 \\
\hline Civil Liberties & -12.206 & 0.47 & 0.000 & 45 \\
\hline Public Sector Competence & -3.364 & 0.01 & 0.553 & 45 \\
\hline Gov't Favor Private Sector Firms & -10.056 & 0.15 & 0.008 & 45 \\
\hline Property Rights & -9.644 & 0.27 & 0.000 & 45 \\
\hline Independent Judiciary & -7.166 & 0.18 & 0.003 & 45 \\
\hline Irregular Payments & -12.413 & 0.26 & 0.000 & 45 \\
\hline Legal Framework & -9.343 & 0.23 & 0.001 & 45 \\
\hline Regulatory Burden & -9.259 & 0.10 & 0.032 & 45 \\
\hline Level of Administrative Corruption & -12.877 & 0.27 & 0.000 & 45 \\
\hline Honoring of Policies through Gov. Transition & -8.685 & 0.11 & 0.021 & 45 \\
\hline Scientific and Research Infrastructure Index & -10.010 & 0.14 & 0.009 & 45 \\
\hline Scientists and Engineers & -0.006 & 0.09 & 0.038 & 45 \\
\hline Technology Position & -7.931 & 0.18 & 0.003 & 45 \\
\hline Institutions & -8.883 & 0.11 & 0.025 & 45 \\
\hline Licensing of Foreign Technology & -11.980 & 0.08 & 0.049 & 45 \\
\hline Company R \& D Spending & -7.802 & 0.12 & 0.020 & 45 \\
\hline Willingness to Absorb New Technology & -15.067 & 0.20 & 0.002 & 45 \\
\hline Importance of Innovation to Revenue & -15.770 & 0.13 & 0.011 & 45 \\
\hline Gov't Purchase Decisions for Tech. Products & -9.316 & 0.06 & 0.109 & 45 \\
\hline
\end{tabular}

Note: * Refer to appendix A for definitions of variables. 
Among the variables in the economic and legal context grouping, all but one (public sector competence) emerge with high statistical significance and the expected negative sign in the $\mathrm{SO}_{2}$ regressions. Some of the measures account for a reasonable degree of explained variance (e.g., civil liberties, property rights, and irregular payments). In general, the administrative infrastructure variables show greater significance and higher degrees of explained variance than the scientific and technical capacity measures. The administrative infrastructure sub-index is highly significant, with a reasonable degree of explained variance. The technical capacity sub-index shows a high degree of significance, but does not account for an especially large amount of explained variance. The overall ELCI is significant and explains a reasonable amount of the variance in $\mathrm{SO}_{2}$ concentrations.

\section{Ranking environmental regulatory quality}

The bilateral, sub-index, and index regressions establish a statistically significant relationship between the various policy measures and environmental performance. In the next stage of analysis, we use the ERRI to explore the differences across countries in environmental regulatory quality.

Table 8 presents countries ranked by absolute ERRI scores. This index (combining the regulatory stringency, structure, subsidies, and enforcement sub-indices $)^{14}$ represents a summary performance measure of the quality of the environmental regulatory system in a country. Among the top-ranked countries are Finland, Sweden, and Singapore. Countries at the bottom include Guatemala, Ecuador, and Paraguay.

Given the significant relationship between income levels and environmental performance, we would expect a similar relationship between income and environmental regulatory quality. What is most interesting in table 8, then, is not so much the fact that Finland outranks Paraguay on regulatory stringency, but the reasons why countries with similar incomes perform so differently. For instance, why does Costa Rica (36th place) do better than Peru (50th place)? And why does Poland (29th) come out way ahead of Russia (57th)?

To control for income differences and hence the level of economic development, table 9 ranks countries by their residuals from the regression of ERRI and GDP per capita (plotted in figure 6). This relative ranking represents a measure of environmental regulatory quality relative to expectations established by income level. Among the low-income countries, Jordan and Jamaica come out on top, while Ecuador and Paraguay trail. Among middle-income countries, Singapore, Estonia, and New Zealand rank high; Israel, Argentina, and Greece lag. Among the wealthiest nations, Finland, Sweden, and the Netherlands lead, while Italy, Norway, and Ireland rank low. The United States occupies the bottom rung of the highincome group ladder.

As noted earlier, ERRI and ELCI are highly correlated. Nevertheless, it is evident that some countries have an economic and legal context that outpaces their environmental regulatory quality, while others have

${ }^{14}$ These sub-indices emerged as significant in the analyses of all three dependent variables. 
Table 8. Environmental regulatory regime index by country, absolute ranking

\begin{tabular}{rlrlll}
\hline Rank & Country & Score & Rank & Country & Score \\
\hline 1 & Finland & 2.303 & 37 & Korea & -0.121 \\
2 & Sweden & 1.772 & 38 & Malaysia & -0.127 \\
3 & Singapore & 1.771 & 39 & Lithuania & -0.146 \\
4 & Netherlands & 1.747 & 40 & Slovak Republic & -0.177 \\
5 & Austria & 1.641 & 41 & Egypt & -0.224 \\
6 & Switzerland & 1.631 & 42 & Panama & -0.242 \\
7 & Germany & 1.522 & 43 & Mauritius & -0.290 \\
8 & France & 1.464 & 44 & China & -0.348 \\
9 & Denmark & 1.384 & 45 & Thailand & -0.389 \\
10 & Iceland & 1.354 & 46 & Colombia & -0.416 \\
11 & New Zealand & 1.299 & 47 & Bulgaria & -0.584 \\
12 & Canada & 1.297 & 48 & Mexico & -0.602 \\
13 & United Kingdom & 1.185 & 49 & Greece & -0.619 \\
14 & United States & 1.184 & 50 & Peru & -0.722 \\
15 & Belgium & 1.159 & 51 & Argentina & -0.732 \\
16 & Australia & 1.083 & 52 & Zimbabwe & -0.732 \\
17 & Japan & 1.057 & 53 & Bolivia & -0.743 \\
18 & Norway & 1.045 & 54 & Indonesia & -0.758 \\
19 & Ireland & 0.546 & 55 & India & -0.759 \\
20 & Italy & 0.498 & 56 & Vietnam & -0.770 \\
21 & Spain & 0.437 & 57 & Russia & -0.895 \\
22 & Estonia & 0.296 & 58 & Sri Lanka & -0.936 \\
23 & Hungary & 0.283 & 59 & Philippines & -1.014 \\
24 & Slovenia & 0.209 & 60 & Dominican Republic & -1.014 \\
25 & Chile & 0.177 & 61 & Venezuela & -1.079 \\
26 & Czech Republic & 0.073 & 62 & Nicaragua & -1.164 \\
27 & Uruguay & 0.059 & 63 & El Salvador & -1.215 \\
28 & Israel & 0.021 & 64 & Romania & -1.268 \\
29 & Poland & 0.005 & 65 & Ukraine & -1.297 \\
30 & Jordan & 0.002 & 66 & Honduras & -1.300 \\
31 & Portugal & -0.028 & 67 & Nigeria & -1.314 \\
32 & South Africa & -0.029 & 68 & Bangladesh & -1.331 \\
33 & Latvia & -0.036 & 69 & Guatemala & -1.532 \\
34 & Jamaica & -0.037 & 70 & Ecuador & -1.616 \\
35 & Brazil & -0.077 & 71 & Paraguay & -1.743 \\
36 & Costa Rica & -0.078 & & & \\
\hline & & & & & \\
\hline
\end{tabular}

advanced environmental regulation faster than their economic and legal development. In Israel, India, Ireland, the United States, South Africa, the Philippines, and Nigeria, environmental regulation lags behind the economic and legal context. In Finland, Austria, New Zealand, Panama, and Bolivia, environmental regulatory quality appears to be ahead of improvements in the broader economic and legal structure. The divergence between ERRI and ELCI, however, was not statistically associated with differences in environmental outcomes. This may be due to the high correlation of ERRI and ELCI in the sample. 
Table 9. Environmental regulatory regime index relative to expected results given GDP per capita, listed by income groups

\begin{tabular}{|c|c|c|c|c|c|c|c|c|}
\hline \multicolumn{3}{|c|}{ Low income countries $(\leq \$ 6,500)$} & \multicolumn{3}{|c|}{ Middle income countries $(\$ 6,500-23,000)$} & \multicolumn{3}{|c|}{ High income countries $(\geq \$ 23,000)$} \\
\hline Rank & Country & Residual & Rank & Country & Residual & Rank & Country & Residual \\
\hline 1 & Jordan & 0.794 & 1 & Singapore & 0.806 & 1 & Finland & 1.165 \\
\hline 2 & Jamaica & 0.793 & 2 & Estonia & 0.614 & 2 & Sweden & 0.725 \\
\hline 3 & Egypt & 0.612 & 3 & New Zealand & 0.612 & 3 & Netherlands & 0.541 \\
\hline 4 & China & 0.455 & 4 & Latvia & 0.499 & 4 & France & 0.404 \\
\hline 5 & Panama & 0.355 & 5 & Chile & 0.494 & 5 & Germany & 0.377 \\
\hline 6 & Vietnam & 0.216 & 6 & Brazil & 0.407 & 6 & Austria & 0.368 \\
\hline 7 & Colombia & 0.204 & 7 & Uruguay & 0.402 & 7 & United Kingdom & 0.202 \\
\hline 8 & Bolivia & 0.204 & 8 & Lithuania & 0.374 & 8 & Switzerland & 0.154 \\
\hline 9 & India & 0.188 & 9 & Poland & 0.343 & 9 & Denmark & 0.037 \\
\hline 10 & Zimbabwe & 0.187 & 10 & Hungary & 0.308 & 10 & Canada & -0.112 \\
\hline 11 & Thailand & 0.180 & 11 & South Africa & 0.288 & 11 & Australia & -0.138 \\
\hline 12 & Indonesia & 0.132 & 12 & Costa Rica & 0.235 & 12 & Japan & -0.168 \\
\hline 13 & Bulgaria & 0.078 & 13 & Malaysia & 0.214 & 13 & Belgium & -0.173 \\
\hline 14 & Peru & 0.002 & 14 & Mauritius & -0.003 & 14 & Iceland & -0.184 \\
\hline 15 & Sri Lanka & -0.092 & 15 & Czech Republic & -0.031 & 15 & Italy & -0.495 \\
\hline 16 & Philippines & -0.211 & 16 & Slovak Republic & -0.032 & 16 & Norway & -0.523 \\
\hline 17 & Nicaragua & -0.217 & 17 & Spain & -0.175 & 17 & Ireland & -0.623 \\
\hline 18 & Nigeria & -0.225 & 18 & Slovenia & -0.211 & 18 & United States & -0.792 \\
\hline 19 & Bangladesh & -0.307 & 19 & Mexico & -0.259 & & & \\
\hline 20 & Honduras & -0.359 & 20 & Portugal & -0.426 & & & \\
\hline 21 & Dominican Republic & -0.397 & 21 & Russia & -0.487 & & & \\
\hline 22 & Venezuela & -0.436 & 22 & Korea & -0.558 & & & \\
\hline 23 & El Salvador & -0.461 & 23 & Israel & -0.626 & & & \\
\hline 24 & Ukraine & -0.470 & 24 & Argentina & -0.705 & & & \\
\hline 25 & Romania & -0.684 & 25 & Greece & -0.964 & & & \\
\hline 26 & Guatemala & -0.714 & & & & & & \\
\hline 27 & Ecuador & -0.730 & & & & & & \\
\hline 28 & Paraguay & -0.981 & & & & & & \\
\hline
\end{tabular}




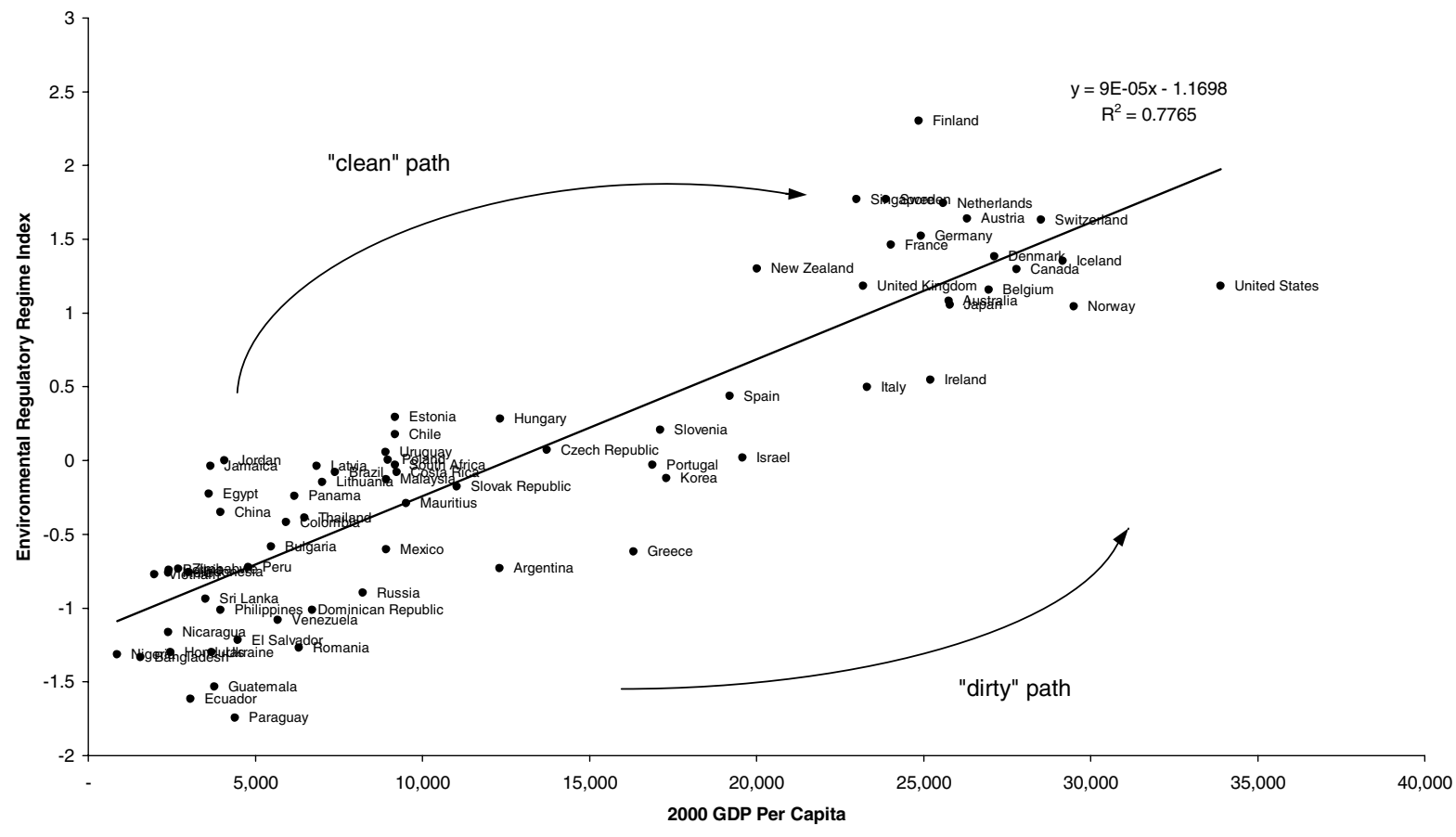

Note: Both linear and quadratic model are tested. The coefficient of the quadratic term is insignificant, hence the linear model is applied.

Figure 6. Relationship between the environmental regulatory regime index and GDP per capita 


\section{The relationship between environmental performance and competitiveness}

Finally, we turn to the question of whether environmental regulatory stringency detracts from or contributes to economic progress. Figure 7 shows that the quality of a nation's environmental regulatory regime is strongly and positively correlated with its competitiveness as measured by the World Economic Forum's Current Competitiveness Index (CCI). ${ }^{15}$ Many of the nations with top-tier competitiveness rankings also have strong environmental performance scores. Finland, for example, ranks at the top of the ERRI and at the top of the CCI. The United States stands out as an exception with a high CCI rank and a relatively low environmental regulation score.

The correlation revealed in figure 7 does not, of course, prove causation. But the finding that a strong environmental regulatory regime need not preclude top-tier economic performance is itself interesting. The fact that the top environmental performers do not appear to have suffered economically strongly supports the 'soft' version of the 'Porter hypothesis', which argues that environmental progress can be achieved without sacrificing competitiveness (Porter, 1991; Porter and van der Linde, 1995). Whether the 'hard' version of this hypothesis - that countries with aggressive environmental policies and programs will actually enhance their competitiveness - requires time series data that are not yet available.

Figure 6 highlights the development policy choice that every nation faces. Countries would like to move from the lower left corner of the chart, which represents low levels of environmental performance and low national income, to the upper right quadrant, which represents high levels of both environmental performance and income. The question is which path to take. Or, to put it differently, must the environment be sacrificed to achieve economic progress? Those countries above the regression line can be seen as having chosen a 'clean' development trajectory in which environmental regulatory quality advances ahead of economic progress. Those below the line have chosen a relatively 'dirty' path to growth, with relatively lax environmental regulation, in the hope of growing faster.

In addressing this choice, we are able to provide a crude test using the available data. We regress a number of control variables on GDP per capita growth between 1995 and 2000, including the initial level of GDP per capita, gross fixed capita formation as a percentage of GDP, and government spending as a percentage of GDP. We then introduce a variable which measures the residual from the regression of ERRI on GDP per capita (table 10). Countries with positive residuals have an ERRI score that is higher than would be expected given their income. Those with negative

15 The CCI (GCR, 2001) explores the microeconomic bases of a nation's GDP per capita. It is constructed from measures of competitiveness, based primarily on survey data drawn from senior business leaders and government officials. There are two groups of measures, one measuring the sophistication of company operations and strategy and the other addressing the quality of the business environment. A single composite index was created by combining the two groups using common factor analysis. 


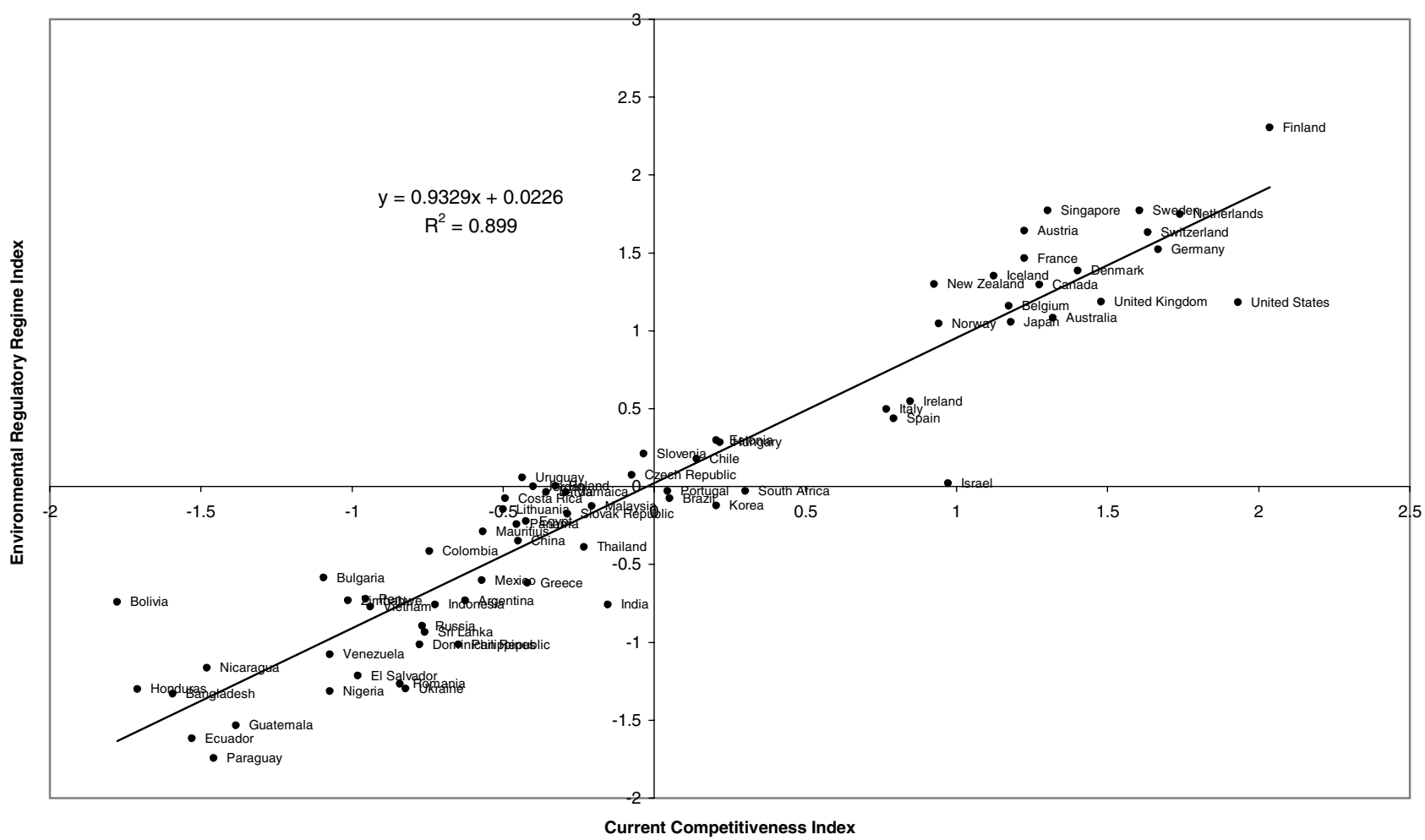

Figure 7. Relationship between the environmental regulatory regime index and current competitiveness 
Table 10. Environmental regulatory stringency and economic growth

\begin{tabular}{|c|c|c|c|c|c|c|}
\hline \multirow[b]{2}{*}{ Variable } & \multicolumn{3}{|c|}{$\begin{array}{c}\text { Model } 1 \text { dependent variable: annual } \\
\text { percentage growth rate of GDP } \\
\text { per capita, 1995-2000 }\end{array}$} & \multicolumn{3}{|c|}{$\begin{array}{c}\text { Model } 2 \text { dependent variable: annual } \\
\text { percentage growth rate of GDP } \\
\text { per capita, 1995-2000 }\end{array}$} \\
\hline & $\begin{array}{l}\text { Parameter } \\
\text { estimate }\end{array}$ & $t$ Value & Prob $>|t|$ & $\begin{array}{l}\text { Parameter } \\
\text { estimate }\end{array}$ & $t$ Value & Prob $>|t|$ \\
\hline Intercept & 1.577 & 3.62 & 0.001 & -2.352 & -1.91 & 0.060 \\
\hline GDP per Capita, 1995 (thousand, ppp) & 0.056 & 1.77 & 0.082 & 0.092 & 2.78 & 0.007 \\
\hline General Government Spending, 2000 & & & & -0.043 & 1.62 & 0.111 \\
\hline Gross Fixed Investment (as \% of GDP) & & & & 0.226 & 5.17 & $<.0001$ \\
\hline $\begin{array}{l}\text { Environmental Regulatory Regime Index Relative } \\
\text { to Expected Given GDP per Capita }\end{array}$ & 0.830 & 1.51 & 0.135 & 0.795 & 1.66 & 0.102 \\
\hline
\end{tabular}


residuals have a lower ERRI position than would be forecast by the country's income level. This variable has a positive sign with significance at virtually the 90 per cent level. Countries that pursue a stringent regulatory regime thus appear to achieve more rapid growth. While tentative, this result suggests the possible superiority of the 'clean development' model. More years of data and better controls will be necessary to validate this finding.

\section{Conclusion}

The results presented here must be seen as preliminary. The data available suffer from many limitations, narrowing the feasible statistical approaches. Precise causal linkages remain unproven. Indeed, a central conclusion of our research is that better environmental data are required at the global, national, local, and corporate levels if a more empirical and systematic approach to environmental improvement is to be implemented.

With these caveats, however, the relationships that do emerge as statistically significant are striking. The analysis provides considerable evidence that cross-country differences in environmental performance are associated, in part, with the quality of the environmental regulatory regime in place. We find that the rigor and structure of environmental regulations have particular impact, as does emphasis on enforcement. The damaging effect of subsidies is also clear. While developing a strong and sophisticated regulatory regime that fully internalizes externalities presents real challenges, ending price-distorting, inefficiency-creating, and pollution-inducing subsidies is within the policy grasp of every nation. Environmental performance appears to improve with certain kinds of information, and to the extent that a nation's environmental regime is reinforced by an environmentally oriented private sector, strong relationships with international environmental bodies also seem to help. Information and institutions seem to have a limited impact on environmental performance based on our analysis. This finding may, in part, be due to weaknesses in the available data.

Our results also suggest that environmental performance requires improvements in a country's broader institutions. In practice, a nation's economic and legal context and its environmental regulatory regime appear to go hand in hand. This association demands further exploration. But the preliminary evidence developed here suggests that countries would benefit environmentally from an emphasis on developing the rule of law, eliminating corruption, and strengthening their governance structures.

The strong association between income and environmental performance also carries important implications. Among other things, it provides powerful corroboration for a policy emphasis on poverty alleviation and the promotion of economic growth as a key mechanism for improving environmental results.

The country rankings that emerge from our analysis largely square with observed reality. The variations in performance highlight the fact that countries range widely in their policy choices and environmental outcomes, even after controlling for level of income. There are clearly better and worse ways to approach pollution control and natural resource management. The data provided here offer some important clues as to where the search for the best practices should begin. 
Fundamentally, our findings suggest that the environment need not be sacrificed on the road to economic progress. Quite to the contrary, the countries that have the most aggressive environmental policy regimes also seem to be the most competitive and economically successful. Moreover, we find preliminary evidence that countries that adopt a stringent environmental regime relative to their income may speed up economic growth rather than retard it.

Our efforts to use statistical methods to explain environmental successes and failures seem to confirm some aspects of the prevailing wisdom. Poverty appears to be significantly correlated with environmental degradation and thus deserves ongoing policy attention. Subsidies not only skew prices and distort trade, but they appear to lead to inefficient production processes and unnecessary pollution as well.

Some new priorities also emerge from this research. Significant environmental gains look to be achievable simply by moving environmental laggards toward the policy approaches of those at the top of the performance ladder. Much greater strategic emphasis might therefore be placed on identifying the best-policy practices and disseminating this information. Likewise, the significance of economic and legal context to environmental results argues for a new focus on governance as the foundation for both environmental and economic progress.

From an over-arching perspective, this study highlights the fact that decision makers in the environmental domain need not rely on guesswork. A more empirically grounded and analytically rigorous approach to pollution control and natural resource management is possible. Our analysis strongly supports the notion that the uncertainties that plague environmental policy making can be reduced. We believe that a robust, statistically serious, and data-driven approach to understanding environmental problems and evaluating policy options could move the environmental field toward decision making based on objective evidence rather than letting strongly held beliefs and emotions create divides that are hard to bridge.

\section{References}

Annan, K. (July 1997), Innaugural Address of the Secretary-General of the United Nations to the International Conference on Governance for Sustainable Growth and Equity (available at www.undp.org/Docs/speeches/Annan).

Antweiler, W., B.R. Copeland, and M. Scott Taylor (August 1998), 'Is free trade good for the environment?', National Bureau of Economic Research Working Paper, No. W6707.

Bakkes, J.A., G.J. Van den Born, R.J. Swart, C.W. Hope, and J.D.E. Parker (1994), An Overview of Environmental Indicators: State of the Art and Perspectives, New York: United Nations Environment Programme.

Barrett, S. and K. Graddy (2000), 'Freedom, growth, and the environment', Environment and Development Economics 5: 433-456.

Bossel, H. (1999), 'Indicators for sustainable development: theory, method, applications', A Report to the Balaton Group, International Institute for Sustainable Development, Winnipeg.

Coalition for Environmentally Responsible Economies (CERES) (1997), 'Green metrics', Coalition for Environmentally Responsible Economies, Boston. 
Dasgupta, S., B. Laplante, and H. Wang (2002), 'Confronting the environmental Kuznets curve', Journal of Economic Perspectives 16: 147-168.

Dasgupta, S., A. Mody, S. Roy, and D. Wheeler (2001), 'Environmental Regulation and development: a cross-country empirical analysis', Oxford Development Studies 29: $173-187$.

Dixon, F. (2002), 'Financial markets and corporate environmental results', in D. Esty and P. Cornelius (eds), Environmental Performance Measurement: The Global Report 2001-2002, New York: Oxford University Press.

Dow Jones and Company (2000), Dow Jones Sustainability Group Index (http:/ / www.sustainability-index.com).

Dua, A. and D.C. Esty (1997), Sustaining the Asia Pacific Miracle: Environmental Protection and Economic Integration, Washington, DC: Institute for International Economics.

Esty, D.C. (1997), 'Environmental protection during the transition to a market economy', in W. Woo, S. Parker, and J. Sachs (eds), Economies in Transition: Asia and Europe, Cambridge, MA: MIT Press.

Esty, D.C. (1998), 'NGOs at the World Trade Organization: cooperation, competition, or exclusion', Journal of International Economic Law 1: 123-147.

Esty, D.C. (2002), 'Why measurement matters', in D. Esty and P. Cornelius (eds), Environmental Performance Measurement: The Global Report 2001-2002, New York: Oxford University Press.

Esty, D.C. and P. Cornelius (2002), Environmental Performance Measurement: The Global Report 2001-2002, New York: Oxford University Press.

Esty, D.C. and M.E. Porter (1998), 'Industrial ecology and competitiveness', Journal of Industrial Ecology 2: 35-43.

Esty, D.C. and M.E. Porter (2000), 'Measuring national environmental performance and its determinants', in M.E. Porter and J. Sachs (eds), The Global Competitiveness Report 2000, New York: Oxford University Press.

Esty, D.C. and M.E. Porter (2001), 'Ranking national environmental regulation and performance: a leading indicator of future competitiveness?', in M.E. Porter, J. Sachs, and A.M. Warner (eds), The Global Competitiveness Report 2001, New York: Oxford University Press.

Esty, D.C. and M.E. Porter (2002), 'National environmental performance measurement and determinants', in D. Esty and P. Cornelius (eds), Environmental Performance Measurement: The Global Report 2001-2002, New York: Oxford University Press.

Esty, D.C., M.A. Levy, T. Srebotnjak, and A. de Sherbinin (2005), Environmental Sustainability Index: Benchmarking National Environmental Stewardship, New Haven: Yale Center for Environmental Law and Policy.

Eurostat (1999), 'Towards environmental pressure indicators', Brussels, European Commission (http:/ / www.e-m-a-i-l.nu/tepi/document.html).

Grossman, G.M. and A.B. Krueger (1995), 'Economic growth and the environment', Quarterly Journal of Economics 110: 353-377.

Hammond, A., A. Adriaanse, E. Rodenberg, D. Bryant, and R. Woodward (1995), Environmental Indicators: A Systematic Approach to Measuring and Reporting on Environmental Policy Performance in the Context of Sustainable Development, Washington: World Resources Institute.

Harbaugh, W., A. Levinson, and D. Wilson (May 2000), 'Reexamining the empirical evidence for an environmental Kuznets curve', National Bureau of Economic Research Working Paper, No. W7711.

International Institute for Sustainable Development (1999), Consultative Group on Sustainable Development Indicators (http:/ /iisd1.iisd.ca/cgsdi/).

Jaffe, A., S. Peterson, and P. Portney (1995), 'Environmental regulation and the competitiveness of US manufacturing: what does the evidence tell us?', Journal of Economic Literature 33: 132-161. 
Kaufmann, R., B. Davisdotter, and S. Garnham (1998), 'The determinants of atmospheric $\mathrm{SO}_{2}$ concentrations: reconsidering the environmental Kuznets curve', Ecological Economics 25: 209-220.

López, R. and S. Mitra (2000), 'Corruption, pollution, and the Kuznets environment curve', Journal of Environmental Economics and Management 40: 137-150.

Organization for Economic Cooperation and Development (1993), 'Core set of indicators for environmental performance reviews', A Synthesis Report by the Group on the State of the Environment, Organization for Economic Cooperation and Development, Paris.

Organization for Economic Cooperation and Development (1998), Towards Sustainable Development: Environmental Indicators, Paris: Organization for Economic Cooperation and Development.

Panayotou, T. (1997), 'Demystifying the environmental Kuznets curve: turning a black box into a policy tool', Environment and Development Economics 2: 465-484.

Panayotou, T. (2000), Environment: Conservation and Competitiveness, Cambridge, MA: Harvard University Press.

Panayotou, T. and J.R. Vincent (1997), 'Environment and competitiveness', Global Competitiveness Report, World Link, London.

Porter, M.E. (1991), 'America's Green Strategy', Scientific American (August).

Porter, M.E., J. Sachs, and A.M. Warner (eds) (2001), The Global Competitive Report 2001, Oxford: Oxford University Press.

Porter, M.E. and C. van der Linde (1995), 'Toward a New Conception of the Environment-Competitiveness Relationship', The Journal of Economic Perspectives 9: 97-118.

Rawlings, J.O., D.A. Dickey, and S.C. Pantula (1998), Applied Regression Analysis: A Research Tool, New York: Springer-Verlag.

Ricketts, T.H. (1999), Terrestrial Ecoregions of North America: A Conservation Assessment, Washington, DC: Island Press.

Sachs, J. (1998), 'Globalization and the rule of law', Yale Law School Occasional Papers, 2nd series, No. 4.

Seldon, T.M. and D. Song (1994), 'Environmental quality and development: is there a Kuznets curve for air pollution emissions?', Journal of Environmental Economics and Management 27: 147-152.

Shafik, N. and S. Bandyopadhyay (1992), Economic Growth and Environmental Quality: Time-Series and Cross-Country Evidence, Washington, DC: World Bank.

Suri, V. and D. Chapman (1998), 'Economic growth, trade and energy: implications for the environmental Kuznets curve', Ecological Economics 25: 195-208.

Toras, M. and J. Boyce (1998), 'Income, inequality, and pollution: a reassessment of the environmental Kuznets curve', Ecological Economics 25: 147-160.

UN Commission on Sustainable Development (1996), Indicators of Sustainable Development Framework and Methodologies, New York: United Nations.

Verfaille, H.A. and R. Bidwell (2000), Measuring Eco-Efficiency: A Guide to Reporting Company Performance, Geneva: World Business Council for Sustainable Development.

World Business Council on Sustainable Development (1998), State-of-Play in EcoEfficiency Indicators: A Tool for Better Decision-Making, Geneva: World Business Council on Sustainable Development.

World Business Council on Sustainable Development (1999), Executive Brief on EcoEfficiency Indicators: A Tool for Better Decision-Making, Geneva: World Business Council on Sustainable Development.

World Commission on Environment and Development (1987), Our Common Future, Oxford: Oxford University Press.

World Economic Forum (2002), 2002 'Environmental sustainability index', World Economic Forum, Geneva. (http://www.ciesin.columbia.edu/indicators/ESI).

York, R., E.A. Rosa, and T. Dietz (2003), 'Footprints on the earth: the environmental consequences of modernity', American Sociological Review 68: 279-300. 
Appendix A: Description of variables

\begin{tabular}{|c|c|c|c|}
\hline Variable & Definition & Measurement & $\begin{array}{l}\text { Source } \\
\text { (WEF/ESI) }\end{array}$ \\
\hline \multicolumn{4}{|c|}{ Environmental Performance } \\
\hline Energy use & $\begin{array}{l}\text { Energy Usage } 1997 \text { (High }=\text { More } \\
\text { Inefficient) }\end{array}$ & $\begin{array}{l}\text { Total energy consumption per unit } \\
\text { of country GDP }\end{array}$ & ESI \\
\hline Urban $\mathrm{SO}_{2}$ & $\begin{array}{l}\text { Urban } \mathrm{SO}_{2} \text { concentration, } 1990-96 \\
\quad \text { (High = More Particulates) }\end{array}$ & $\begin{array}{l}\text { Average normalized mean of total } \\
\mathrm{SO}_{2} \text { per unit of city population }\end{array}$ & ESI \\
\hline Urban particulates & $\begin{array}{l}\text { Urban particulates concentration, 1990-96 } \\
\text { (High = More Particulates) }\end{array}$ & $\begin{array}{l}\text { Average normalized mean of total } \\
\text { suspended particulates per unit } \\
\text { of city population }\end{array}$ & ESI \\
\hline \multicolumn{4}{|c|}{ Environmental Regulatory Regime } \\
\hline \multicolumn{4}{|c|}{ Stringency of standards } \\
\hline Air regulation & $\begin{array}{l}\text { Stringency of air regulations } \\
\text { (High = More Stringent) }\end{array}$ & Survey data (scale 1-7) & WEF \\
\hline Water regulation & $\begin{array}{l}\text { Stringency of water regulations } \\
\text { (High = More Stringent) }\end{array}$ & Survey data (scale 1-7) & WEF \\
\hline Toxic waste regulation & $\begin{array}{l}\text { Stringency of toxic waste regulations } \\
\text { (High = More Stringent) }\end{array}$ & Survey data (scale 1-7) & WEF \\
\hline Chemical regulation & $\begin{array}{l}\text { Stringency of manufacturing chemical use } \\
\text { regulations (High = More Stringent) }\end{array}$ & Survey data (scale 1-7) & WEF \\
\hline Overall regulation & $\begin{array}{l}\text { Stringency of overall environmental } \\
\text { regulation (High = More Stringent }\end{array}$ & Survey data (scale 1-7) & WEF \\
\hline \multicolumn{4}{|l|}{ Regulatory structure } \\
\hline Flexibility & $\begin{array}{l}\text { Options for achieving compliance } \\
\text { in environmental regulations } \\
\text { (High = Many Options) }\end{array}$ & Survey data (scale 1-7) & WEF \\
\hline
\end{tabular}


Stability

Early or late

Compliance Hurts or Helps Competitiveness Regulation Adversarial or Cooperative

\section{Information}

ESI Variables-\%

Sustainable development info

Number of Sectoral EIA Guidelines

Number of Environmental Strategies \& Action Plans

\section{Subsidies}

Government subsidies

Regulatory enforcement Enforcement
Environmental regulations in your country are confusing and frequently changing $($ High $=$ Stable $)$

Environmental regulations are enacted ahead or much later than other countries (High $=$ Ahead)

Complying with environmental standards hurts/helps competitiveness (High $=$ helps)

Environmental gains are achieved through adversarial means or government-business cooperation $($ High $=$ Cooperative $)$

Percentage of ESI variables in publicly available data sets

Availability of sustainable development information at the national level

Number of sectoral EIA Guidelines

Number of Environmental Strategies \& Action Plans

Government subsidies in your country encourage inefficient use of energy or materials or there are no subsidies $($ High $=$ High Subsidies $)$

Environmental regulations are not enforced or enforced erratically or are

enforced consistently and fairly

(High = Consistently and Fairly)
Survey data (scale 1-7)

WEF

Survey data (scale 1-7)

WEF

Survey data (scale 1-7) WEF

Survey data (scale 1-7) WEF

$\%$ of total ESI variables

ESI

$(n=64)$

ESI

ESI

ESI

Survey data (scale 1-7)

WEF

Survey data (scale 1-7)

WEF 
Administrative infrastructure quality Civil and Political Liberties

Public sector competence

\section{Favoritism}

Property rights

Independent judiciary
Definition

Measurement

Source

Compliance with international agreements is a high priority in your country's government $($ High $=$ Agree $)$

Number of IUCN membership organizations, 1998

Number of memberships in environmental intergovernmental organizations, 1998

How many companies utilize environmental management system such as ISO 14000 (High $=$ Most $)$

Survey data (scale 1-7)

WEF

(per million population)

ESI

frequency count

ESI

Survey data (scale 1-7)

WEF

ESI

Index ranging from 1 (Low levels of liberties) to 7 (High levels)

The competence of personnel in the public sector is higher or lower than in the private sector (High $=$ Higher than Private Sector)

Public sector officials tend to favor well-connected private firms and individuals (High $=$ Disagree)

Property rights are unclear and unprotected by law or are clearly delineated and protected by law $($ High $=$ Clearly Delineated and Protected $)$

The judiciary in your country is independent and not subject to interference by the government and/or parties to the dispute (High = True) 
Irregular payments

Trusted legal framework

Regulatory Burden

Level of Administrative Corruption

Honoring of Policies through Gov. Transition

Scientific and research infrastructure Scientists and engineers

Technology position

Institutions

Licensing foreign technology

Intellectual property protection
Irregular payments connected with import-export permits, business licenses, exchange controls, tax assessments, etc. (High $=$ Never Occur)

A trusted legal framework exists in your country for private business to challenge the legality of government actions and/or regulations (High $=$ True)

Administrative regulations in your country are burdensome/not burdensome $($ High $=$ Not $)$

Do other firms' unfair or corrupt activities impose costs on your firm (High $=$ No Costs)

Do new governments honor the contractual commitments and obligations of previous regimes $($ High $=$ Honor $)$

Research and development scientists and engineers Country's position in technology generally lags behind most countries or is a leader (High = Leader) Scientific research institutions in your country are not internationally reputable (High $=$ World Class)

Licensing of foreign technology is uncommon or is a common means to acquire new technology $($ High $=$ Common $)$

Intellectual property in your country is or is not adequately protected $(\mathrm{High}=$ Well Protected $)$
Survey data (scale 1-7) 
Appendix A: Continued

\begin{tabular}{|c|c|c|c|}
\hline Variable & Definition & Measurement & Source (WEF/ESI) \\
\hline Company R \& D spending & $\begin{array}{l}\text { Companies in your country do or do not spend much on } \\
\text { R \& D relative to international peers (High = Spend } \\
\text { Heavily on R \& D) }\end{array}$ & Survey data (scale 1-7) & WEF \\
\hline $\begin{array}{l}\text { Willingness to Absorb } \\
\text { New Technology }\end{array}$ & $\begin{array}{l}\text { Companies in your country are not interested/aggressive } \\
\text { in absorbing new technology (High }=\text { Aggressive) }\end{array}$ & Survey data (scale 1-7) & WEF \\
\hline $\begin{array}{l}\text { Importance of Innovation } \\
\text { to Revenue }\end{array}$ & $\begin{array}{l}\text { In your business, continuous innovation plays a major role } \\
\text { in generating revenue not true/true (High }=\text { True) }\end{array}$ & Survey data (scale 1-7) & WEF \\
\hline $\begin{array}{l}\text { Gov't Purchase Decisions } \\
\text { for Tech. Products }\end{array}$ & $\begin{array}{l}\text { Government purchase decisions for technology products } \\
\text { are based solely on price/on technology and encourage } \\
\text { innovation (High = On Technology) }\end{array}$ & Survey data (scale 1-7) & WEF \\
\hline
\end{tabular}


Appendix B: Factor analysis results

\begin{tabular}{|c|c|c|c|c|}
\hline & \multicolumn{4}{|c|}{ First factor } \\
\hline & $\begin{array}{l}\text { First } \\
\text { eigen } \\
\text { value }\end{array}$ & $\begin{array}{l}\text { Difference } \\
\text { from } \\
\text { second } E V\end{array}$ & $\begin{array}{l}\% \text { of } \\
\text { variance } \\
\text { explained }\end{array}$ & $\begin{array}{l}\text { Score } \\
\text { coefficient }\end{array}$ \\
\hline Stringency Sub-Index & 3.97 & 3.95 & 99.16 & \\
\hline Air Regulation & & & & 0.251 \\
\hline Water Regulation & & & & 0.251 \\
\hline Toxic Waste Regulation & & & & 0.251 \\
\hline Chemical Regulation & & & & 0.251 \\
\hline Overall Regulation & & & & $*$ \\
\hline Regulatory Structure Sub-Index & 4.05 & 3.60 & 81.08 & \\
\hline Options for Compliance & & & & 0.216 \\
\hline Confusing and Changing & & & & 0.239 \\
\hline Early or Late & & & & 0.221 \\
\hline $\begin{array}{l}\text { Compliance Hurts or Helps } \\
\text { Competitiveness }\end{array}$ & & & & 0.224 \\
\hline $\begin{array}{l}\text { Regulation Adversarial or } \\
\text { Cooperative }\end{array}$ & & & & 0.210 \\
\hline Information Sub-Index & 1.15 & 0.29 & 57.3138 & \\
\hline ESI-Variables \%-available & & & & 0.660 \\
\hline Sustainable Development Info & & & & 0.660 \\
\hline $\begin{array}{l}\text { Number of Sectoral EIA } \\
\text { Guidelines }\end{array}$ & & & & $*$ \\
\hline $\begin{array}{l}\text { Number of Environmental } \\
\text { Strategies \& Action Plans }\end{array}$ & & & & $*$ \\
\hline $\begin{array}{l}\text { Regulatory Enforcement } \\
\text { Sub-Index }\end{array}$ & 1.93 & 1.86 & 96.38 & \\
\hline Enforcement & & & & 0.509 \\
\hline International Agreements & & & & 0.509 \\
\hline $\begin{array}{l}\text { Environmental Institutions } \\
\text { Sub-Index }\end{array}$ & 1.59 & 1.19 & 79.72 & \\
\hline IUCN & & & & $*$ \\
\hline Memberships & & & & 0.560 \\
\hline Prevalence of ISO 14000 & & & & 0.560 \\
\hline $\begin{array}{l}\text { Administrative Infrastructure } \\
\text { Quality Index }\end{array}$ & 5.35 & 5.14 & 89.09 & \\
\hline Civil Liberties & & & & $*$ \\
\hline Public Sector Competence & & & & $*$ \\
\hline Gov't Favor Private Sector Firms & & & & 0.172 \\
\hline Property Rights & & & & 0.178 \\
\hline Independent Judiciary & & & & 0.179 \\
\hline Irregular Payments & & & & * \\
\hline Legal Framework & & & & 0.180 \\
\hline Regulatory Burden & & & & $*$ \\
\hline $\begin{array}{l}\text { Level of Administrative } \\
\text { Corruption }\end{array}$ & & & & 0.176 \\
\hline $\begin{array}{l}\text { Honoring of Policies through } \\
\text { Gov. Transition }\end{array}$ & & & & 0.175 \\
\hline
\end{tabular}


Appendix B: Continued

\begin{tabular}{|c|c|c|c|c|}
\hline & \multicolumn{4}{|c|}{ First factor } \\
\hline & $\begin{array}{l}\text { First } \\
\text { eigen } \\
\text { value }\end{array}$ & $\begin{array}{l}\text { Difference } \\
\text { from } \\
\text { second } E V\end{array}$ & $\begin{array}{l}\% \text { of } \\
\text { variance } \\
\text { explained }\end{array}$ & $\begin{array}{l}\text { Score } \\
\text { coefficient }\end{array}$ \\
\hline $\begin{array}{l}\text { Scientific and Research } \\
\text { Infrastructure Index }\end{array}$ & 4.52 & 4.32 & 90.38 & \\
\hline Scientists and Engineers & & & & * \\
\hline Technology Position & & & & 0.214 \\
\hline Institutions & & & & 0.212 \\
\hline $\begin{array}{l}\text { Licensing of Foreign } \\
\text { Technology }\end{array}$ & & & & $*$ \\
\hline Company R \& D Spending & & & & 0.212 \\
\hline $\begin{array}{l}\text { Willingness to Absorb } \\
\text { New Technology }\end{array}$ & & & & 0.210 \\
\hline $\begin{array}{l}\text { Importance of Innovation } \\
\text { to Revenue }\end{array}$ & & & & * \\
\hline $\begin{array}{l}\text { Gov't Purchase Decisions for } \\
\text { Tech. Products }\end{array}$ & & & & 0.203 \\
\hline Rollup of Sub-Indices & & & & \\
\hline $\begin{array}{l}\text { Environmental Regulatory } \\
\text { Regime Index }\end{array}$ & 3.46 & 3.06 & 86.56 & \\
\hline Stringency Sub-Index & & & & 0.279 \\
\hline Regulatory Structure Sub-Index & & & & 0.274 \\
\hline Government Subsidies & & & & -0.238 \\
\hline $\begin{array}{l}\text { Regulatory Enforcement } \\
\text { Sub-Index }\end{array}$ & & & & 0.281 \\
\hline $\begin{array}{l}\text { Economic and Legal } \\
\text { Context Index }\end{array}$ & 1.90 & 1.79 & 94.81 & \\
\hline $\begin{array}{l}\text { Administrative Infrastructure } \\
\text { Quality Index }\end{array}$ & & & & 0.513 \\
\hline $\begin{array}{l}\text { Scientific and Research } \\
\text { Infrastructure Index }\end{array}$ & & & & 0.513 \\
\hline
\end{tabular}

Note: * means that variable is not included in the corresponding index. 
Reproduced with permission of the copyright owner. Further reproduction prohibited without permission. 